Rozalia Sasor (1) http://orcid.org/0000-0003-1461-8453

Uniwersytet Jagielloński, Kraków

rsasor@gmail.com

\title{
Legenda o siedmiu infantach $z$ Lary: historia tekstu
}

\section{Abstract \\ The Legend of the Seven Infants of Lara. A Commentary and Translation}

The text published in this issue has two parts: a critical apparatus consisting of the introduction and footnotes, and a translation into Polish of the prose version of the Legend of the Seven Infants of Lara from manuscript E2 of Estoria de Espanna by Alfonso X the Wise. The critical part contains a discussion of three main research problems, which include the historicity of events and characters, potential sources of inspiration for the authors of subsequent variants of the Legend, and the relationship between these variants. Here we also find the characteristics of the source text of the translation, i.e. the royal chronicle mentioned above. The discussion of historical events and characters appearing in the legend is based on a comparative analysis of the canonical study of the subject by Ramón Manéndez Pidal included in the monograph La leyenda de los Infantes de Lara ( ${ }^{\text {rd }}$ edition, 1971), as well as historical sources and the latest studies by Spanish and foreign scholars, often critical of Pidal's research. Potential influences on the shape of the legend, originating mainly from the French epic, have been indicated for each of the threads, the content of which brings to mind associations with the texts written earlier. The relationship between the different variants of the legend is explained by the evolution of the text from the oldest song of an informative character (Spanish canto noticiero), to first and second epic songs, which have not survived to date, to the prose versions in the chronicles Estoria de Espanna and Crónica de 1344 by Pedro Alfonso, Count de Barcelos. The description of the different variants is complemented by a tabular 
summary of the most important differences between the prose versions of the legend from both chronicles.

The translation of the chapters of Estoria de Espanna containing the story of seven infants is based on a variant of the chronicle called Versión amplificada de 1289 (Extended Version from 1289), which belongs to the so-called post-Alfonsian chronicles and was written after the death of Alfonso X, during the reign of his son, Sancho IV the Brave. It is the oldest preserved version of the Legend of the Seven Infants of Lara, which is the basis for the later variants. The source for the translation is manuscript E2 (MS X-I-4, Biblioteca del Monasterio de San Lorenzo, El Escorial, Madrid) known in its two modern editions: Primera Crónica General de España, edited by Ramón Menédez Pidal, and Estoria de Espanna Digital, an online edition.

Keywords: Siete infantes de Lara, Legend of the Seven Infants of Lara, Primera Crónica General, Estoria de Espanna, Castilian epic, Mediaeval Spanish literature, Alfonso X the Wise

\section{Historyczność legendy}

Mimo że legenda o siedmiu infantach z Lary należy do najpopularniejszych w literaturze hiszpańskiej wątków epickich, jej źródło wciąż pozostaje nieznane. Najwcześniejszą zachowaną wersję podaje trzynastowieczna Estoria de Espanna, zwana też Pierwsza kronika powszechna Hiszpanii (Primera crónica general de España; dalej PCG) Alfonsa X Mądrego, która stanowi punkt wyjścia dla późniejszych wariantów obecnych w innych kronikach, w romancach, sztukach teatralnych czy, współcześnie, filmach.

Opowieść rozpoczyna relacja z odbywającego się w Burgos wesela Ruya Velázqueza, pana na Bilvestre i wuja infantów z Lary, z krewną Garcíi Fernándeza hrabiego Kastylii, Lambrą de Bureba. Podczas rycerskich zabaw uświetniających zaślubiny dochodzi do zatargu między Lambrą a Gonzalem Gonzálezem, najmłodszym z siedmiu infantów, który zabija kuzyna panny młodej, Álvara Sáncheza. Znieważona 
Lambra domaga się od męża zadośćuczynienia, co prowadzi do eskalacji konfliktu, w którym do walki stają dwie zbrojne drużyny: Ruya Velázqueza i siedmiu braci. Do rozlewu krwi nie dochodzi tylko dzięki interwencji hrabiego Kastylii i ojca infantów, Gonzala Gústioza. Bracia uzyskują przebaczenie Lambry, choć jak się później okaże - tylko pozorne, i po zakończeniu wesela wyruszają w orszaku młodej żony do jej posiadłości w Barbadillo, gdzie dochodzi do kolejnej, dość kuriozalnej zniewagi. Otóż Lambra, urażona zachowaniem Gonzala Gonzáleza, wysyła sługę, aby ten rzucił w infanta ogórkiem napełnionym krwią. Na zemstę nie trzeba długo czekać, infanci wyciągają ukrytego pod płaszczem Lambry sługę i zabijają go na miejscu, ochlapując krwią ciotkę. Następnie odjeżdżają do rodzinnych włości w Salas, zaś pogrążona w żałobie Lambra czeka na powrót męża, by ten pomścił zuchwalstwo braci. Na wieść o wydarzeniach w Barbadillo Ruy Velázquez reaguje, planując złożoną intrygę, której celem jest doprowadzenie do śmierci ojca i jego siedmiu synów w taki sposób, aby ani on sam, ani żaden z jego rycerzy nie musiał kalać się zabójstwem chrześcijanina. Posyła Gonzala Gústioza do Kordoby z listem do Almanzora, w którym żąda zabicia posłańca, natomiast infantów zabiera ze sobą na wyprawę przeciwko Maurom. Podczas walki infanci, pozbawieni wsparcia wojsk Velázqueza, zostają otoczeni i ścięci, a ich głowy dostarczone do pałacu Almanzora, gdzie rozpoznaje je przetrzymywany $\mathrm{w}$ areszcie ojciec. Poruszony rozpaczą więźnia władca Kordoby uwalnia Gústioza, który wraca do Salas. Po wielu latach przybywa do niego Mudarra, syn, którego urodziła Gústiozowi krewna Almanzora, opiekująca się chrześcijańskim rycerzem podczas jego niewoli. Mudarra w imieniu ojca oraz zabitych braci domaga się przed obliczem hrabiego Kastylii sprawiedliwości i dokonuje zemsty na Ruyu Velázquezie oraz jego żonie.

Ramón Menéndez Pidal ${ }^{1}$ wydzielił w przytoczonej wersji legendy dwie części, pierwszą o charakterze historycznym, obejmującą

1 Pierwszym opracowaniem Legendy o siedmiu infantach z Lary jest monografia wybitnego hiszpańskiego mediewisty Ramóna Menéndeza Pidala La leyenda de los 
konflikt między siedmioma infantami oraz Ruyem Velázquezem i Lambrą, i drugą, podejmującą wątek zemsty Mudarry, stanowiący jego zdaniem fikcyjne uzupełnienie tragicznej opowieści. Pidal zakładał, że część historyczna powstała jako niewielkich rozmiarów pieśń epicka o charakterze informacyjnym (hiszp. canto noticiero) krótko po 974 roku, to jest po ataku Garcíi Fernándeza na Dezę (prowincja Soria), i została uzupełniona niedługo później o apokryficzny wątek Mudarry, czyli wskazaną przez badacza część drugą. Następnie, około 1250 roku, całość przemodelowano zgodnie z gustami epoki, a streszczenie powstałej w ten sposób pieśni włączono do Pierwszej kroniki powszechnej. Ponieważ wariant legendy przytaczany przez Kronikę z 1344 (Crónica de 1344, dalej C1344) znacząco rozbudowuje część drugą, Pidal uznał, że jego podstawą musiała być jakaś inna pieśń, której powstanie datuje na około 1320 rok.

Niemniej jednak o wydarzeniach historycznych stanowiących źródło legendy nie wiadomo nic pewnego, jako że nie są wzmiankowane ani w kronikach łacińskich, ani w dokumentach prawnych $\mathrm{z}$ epoki, a pierwszą znaną relację podaje dopiero wspominana wyżej Pierwsza kronika powszechna w wariancie spisanym za panowania syna władcy, Sancha IV, czyli około 1289 roku. Przekonanie o historyczności legendy utrzymywało się początkowo dzięki autorytetowi PCG, jednak tragiczne losy infantów z Lary nie wytrzymały konfrontacji z krytyką oświeceniową i od XVIII wieku zaczęły się pojawiać opracowania odmawiające autentyczności zarówno głównym bohaterom dramatu, jak i samym zdarzeniom. W tym świetle Pidalowski schemat ewolucji tekstu może zaskakiwać, lecz wynika on przede wszystkim ze sformułowanej przez badacza koncepcji pochodzenia epiki kastylijskiej, określanej jako teoria tradycjonalistyczna, to znaczy zakładająca

Infantes de Lara, opublikowana po raz pierwszy w 1896 roku (Madrid), a następnie rozszerzona i poprawiona w kolejnych dwóch wydaniach: Madrid 1934; Madrid 1971. Mimo upływu czasu Pidalowska monografia wciąż stanowi punkt odniesienia dla badaczy zajmujących się zarówno legendą, jak i epiką kastylijską w ogóle. Również niniejszy artykuł odwołuje się do zawartych w niej ustaleń, o ile nie zostały odrzucone przez późniejszą krytykę. 
istnienie w przekazie ustnym pieśni epickich, dziś zagubionych, odnoszących się do wydarzeń historycznych ${ }^{2}$. Próba ich rekonstrukcji w monografii La leyenda de los Infantes de Lara opiera się jednak na dość swobodnej, czasem wręcz życzeniowej interpretacji jednostkowych faktów historycznych, udokumentowanych w źródłach, które nie zawsze poddano należytej krytyce ${ }^{3}$. Dlatego dzisiaj, po ponad stu latach od pierwszego wydania La leyenda..., można zaobserwować w pracach badaczy przedmiotu pojawienie się tendencji odwrotnej, to znaczy takiej, która odrzuca historyczność legendy i doszukuje się jej korzeni we wpływach epiki francuskiej ${ }^{4}$. Lecz i to spojrzenie nie jest wolne od arbitralności, której przyczyną jest zapewne chęć wyjaśnienia tego, czego wyjaśnić się nie da. A to z powodu braku materiału badawczego, czyli w tym przypadku oryginalnej lub oryginalnych pieśni o siedmiu infantach z Lary. Spróbujmy jednak przyjrzeć się temu, co się zachowało i co może podlegać interpretacji.

Przynajmniej niektórzy z pojawiających się w legendzie bohaterów to postaci albo dobrze znane historykom, jak Almanzor czy hrabia Kastylii, albo przynajmniej nieobce, poświadczone w zapiskach z czasów panowania Garcíi Fernándeza, jak Gonzalo Gústioz czy Ruy Velázquez. Abu Amir (ok. 938-1002) o przydomku Al-Mansur, czyli

2 Szerzej o pochodzeniu epiki kastylijskiej w: R. Sasor, Zaginiona epika kastylijska, „Terminus” 20 (2018), z. 3 (48), s. 351-380. Tam też bibliografia tematu.

${ }^{3}$ Najciekawszym opracowaniem krytycznym Pidalowskiej rekonstrukcji jest artykuł Julia Escalony, Épica, crónicas y genealogías. En torno a la historicidad de la Leyenda de los infantes de Lara, „Cahiers de linguistique hispanique médiévale” 23 (2000), s. 113-176, który, jak sam autor zauważył, stanowi zwrot kopernikański w interpretacji tekstu. Mimo że również Escalona nie ustrzegł się przed uproszczeniami, na przykład gdy stwierdza, że tekst reprezentuje punkt widzenia „z Salas”, nie można odmówić mu rzetelności ani wartości naukowej. Rozwinięciem tez stawianych przez Escalonę jest artykuł Mercedes Vaquero, Siete infantes de Lara: historia y ficción en la épica castellana medieval, „Cahiers d'études hispaniques médiévales” 36 (2013), s. 83-102.

4 Najnowsze zestawienie wątków obecnych w tekście legendy i w pieśniach należących do epiki francuskiej podaje Irene Zaderenko, El tema de la traición en Los siete infantes de Lara y su tradición en la épica románica, „Bulletin of Hispanic Studies" 78 (2001), issue 2, s. 177-190. 
Zwycięzca, znany w Europie jako Almanzor, po śmierci Al-Hakama II sprawował w kalifacie kordobańskim władzę nieograniczoną. Poprowadził przeciw chrześcijanom pięćdziesiąt siedem kampanii, z których nie przegrał żadnej, między innymi w 985 roku złupił Barcelonę, a w 997 roku Santiago de Compostela, skąd zabrał katedralne dzwony. Almanzor znany jest również w naszym kraju, choćby z ballady Alpuhara z poematu Konrad Wallenrod Adama Mickiewicza, dlatego warto zwrócić uwagę na osoby słabiej rozpoznawalne przez polskich czytelników, a ważne dla hiszpańskiej tradycji. Hrabia García Fernández ${ }^{5}$ (Burgos, 942/943 - Medinaceli, 995), hrabia Kastylii w latach 970-995, to syn Sanchy Sánchez z Nawarry i Fernána Gonzáleza, uznanego przez tradycję literacką za ojca niepodległej Kastylii ${ }^{6}$. Jego panowanie, po początkowym okresie pokoju za rządów Al-Hakama II, upłynęło pod znakiem nieustających walk granicznych z muzułmanami dowodzonymi przez Almanzora. Podczas jednej z takich potyczek, w maju 995 roku, hrabia został ciężko ranny i mimo opieki medycznej, udzielonej przez podlegającego kalifowi gubernatora Medinaceli, zmarł dwa miesiące później, 29 czerwca. Jego głowę jako trofeum odesłano do Kordoby i na życzenie Almanzora przekazano chrześcijanom, którzy ją pochowali w kościele Trzech Świętych, natomiast reszta ciała została pogrzebana na miejscu, w Medinaceli. Niedługo potem, około 1000 roku, szczątki przeniesiono do klasztoru San Pedro de Cardeña i złożono w ozdobnym sarkofagu, tym razem kompletne.

Z czasów panowania hrabiego nie zachowały się żadne dane, które mogłyby poświadczyć o historyczności legendy o siedmiu infantach z Lary, prócz dwóch bardzo luźno powiązanych z jej akcją epizodów.

5 Szczegółowy opis czasów panowania Garcíi Fernándeza podaje Gonzalo Martínez Diez, El condado de Castilla, 711-1038: la historia frente a la leyenda, vol. 2, Madrid 2005, s. 460 i nn.

${ }^{6}$ Taką wersję historii przekazuje erudycyjny poemat epicki Pieśń o Fernánie Gonzálezie (Poema de Fernán González, druga połowa XIII w.), gdy tymczasem Fernán González jedynie umocnił hrabstwo terytorialnie i politycznie, nie zrywając więzi feudalnych z monarchią leońską, uzyskał także prawo dziedzicznego przekazywania tytułu. 
Z annałów kalifa Al-Hakama II, znanych jako Anales palatinos Isy al-Raziego, obejmujących lata 971-975 i skopiowanych przez Ibn Hayyana w kompilacji tekstów historycznych Muqtabis (X/XI w.), wiadomo, że García Fernández, podobnie jak inni władcy chrześcijańscy, wysyłał do Kordoby poselstwa dyplomatyczne. Jedna z takich ambasad została 1 sierpnia 974 roku uroczyście przyjęta przez samego kalifa, posłowie spędzili w Kordobie ponad miesiąc i 11 września wyruszyli z powrotem do Kastylii. Lecz nie dotarli do celu podróży, ponieważ już 12 września do stolicy kalifatu dotarła wiadomość o ataku na Dezę i zabiciu jej muzułmańskich gubernatorów, co było równoznaczne z naruszeniem przez Garcíę Fernándeza układu pokojowego. Kastylijscy posłowie zostali natychmiast zawróceni z drogi i wtrąceni do więzienia ${ }^{7}$. A choć ich personalia i los pozostają dzisiaj nieznane, podobieństwo do sceny uwięzienia Gonzala Gústioza, ojca infantów, przez Almanzora skłoniło Menéndeza Pidala do wysunięcia hipotezy, że pierwsza część legendy stanowi poetyckie przekształcenie tych właśnie zdarzeń ${ }^{8}$ Jednak uważna analiza porównawcza każe odrzucić Pidalowską analogię jako mało przekonującą. Najazd na Dezę zakończył się niewątpliwym sukcesem wojsk chrześcijańskich, gdy tymczasem w potyczce na polach Almenaru zginęli wszyscy atakujący: siedmiu infantów, ich piastun oraz pięciuset rycerzy. Również chronologia wydarzeń nie odpowiada faktom. Poselstwo

7 El califato de Córdoba en el "Muqtabis" de Ibn Hayyán. Anales palatinos del Califa de Córdoba al-Hakam II, por Isa ibn Ahmad al-Razi (360-364 H. = 971-975 J. C.), ed. y trad. E. García Gómez, Madrid 1967, s. 173-174; J. Escalona, Épica..., s. 117, 119; R. Menéndez Pidal, Córdoba y la Leyenda de los Infantes de Lara, w: idem, Los godos y la epopeya española, Madrid 1969, s. 211-240.

${ }^{8}$ Pidalowską hipotezę podtrzymują całe pokolenia badaczy aż po dzień dzisiejszy, choć nie zawsze z takim samym zapałem jak jej autor. Na przykład Alan Deyermond zauważył pewne podobieństwo zalążka legendy, rozumianego jako uwięzienie Gústioza na dworze Almanzora, do epizodu, w którym atak wojsk kastylijskich doprowadził do uwięzienia przebywających w Kordobie ambasadorów, jednak, jak podkreślał, jądrem legendy jest motyw wewnętrznego konfliktu dwóch rodów, czyli zniewagi i następującej po niej krwawej zemsty. A. Deyermond, El «Cantar de Mio Cid» y la épica medieval española, Barcelona 1987, s. 75-76. 
hrabiego Kastylii zatrzymano po otrzymaniu wiadomości o najeździe, zaś Gonzala Gústioza wtrącono do więzienia jeszcze przed walką, której plany nieświadomy niczego poseł przekazał Almanzorowi w dostarczonym liście.

Podobnie trudno stwierdzić, jaki - i czy w ogóle jakiś - wpływ na kształt legendy miały wypadki związane z buntem Sancha, syna Garcíi Fernándeza, przeciw ojcu. O przyczynach, a także przebiegu rebelii nie wiemy prawie nic prócz tego, że hrabstwo podzieliło się na dwa obozy, zwolennicy Sancha, skupieni między innymi w rejonie Bureby, stanowili mniejszość, zaś sam Sancho paktował z Almanzorem, próbując z pomocą wojsk arabskich uzyskać przewagę nad ojcem. Być może to pamięć o podważających hrabiowską władzę burebianach stoi za przypisaniem Lambrze, spiritus movens tragedii infantów, pochodzenia z tej miejscowości, lecz jest to przypuszczenie oparte na tak niepewnych podstawach, że trudno je rozważać. Natomiast nie ulega wątpliwości, że intensywne walki na chrześcijańsko-muzułmańskim pograniczu, trwające przez niemal piętnaście lat panowania hrabiego, stały się pożywką dla wyobraźni poetyckiej kastylijskich żonglerów i znalazły odbicie w tle legendy o siedmiu infantach, a w niezachowanej do naszych czasów ${ }^{\star}$ Pieśni o zdradzieckiej hrabinie ${ }^{9}$ topos niewiernej żony dybiącej na życie męża uhistoryczniono, tłumacząc nim śmierć hrabiego z rąk muzułmanów.

Mimo że dysponujemy dość sporą wiedzą na temat polityki kastylijskiej w X wieku, materiał źródłowy nie pozwala na identyfikację działań podejmowanych przez hrabiego Garcíę Fernándeza i jego otoczenie z treścią legendy. Tym trudniej będzie znaleźć takie zależności w przypadku pozostałych bohaterów, o których wiemy dużo mniej lub zgoła nic. Osoba niejakiego Gonzala Gústioza pojawia się w licznych dokumentach związanych z kastylijskim dworem hrabiów Fernána Gonzáleza i Garcíi Fernándeza, chociaż w większości, jak

${ }^{9}$ Oznaczam asteryskiem tytuły tych kastylijskich pieśni epickich, które badacze przedmiotu uważają za dzieła zaginione, ale istniejące w przeszłości w przekazie ustnym lub niezachowanych wersjach spisanych. 
na przykład w tych z lat 963, 969 oraz 972, figuruje jedynie podpis: Gundesalvo Gudestioz ${ }^{10}$, więc trudno orzec coś pewnego na temat osoby sygnatariusza prócz tego, że pochodził z okolic Burgos, nie zaś Salas czy Lary. Ignacio Álvarez Borge ${ }^{11}$ poddał krytycznej rewizji zebrane przez Menéndeza Pidala wzmianki i doszedł do wniosku, że Gundesalvo Gudestioz musiał należeć do osiadłego na południowy wschód od Burgos rodu szlacheckiego, a jego dziadkiem byłby inny Gonzalo Gudestioz, pojawiający się w dokumencie darowizny młynów w Ibeas datowanym na 921 rok, zaś ojcem Gudestio González, którego podpis znajduje się w dokumencie z 924 roku. Ponadto, w latach 944-964, w kilku dyplomach potwierdzających darowizny na rzecz klasztorów oraz ich zwolnienie z obciążeń podatkowych widnieje podpis kolejnego, być może, członka rodziny - Diega Gudestioza, utrzymującego relacje z arystokracją kastylijską, w tym z samym hrabią Fernánem Gonzálezem² ${ }^{12}$ Po roku 972 Gonzalo Gudestioz znika z dokumentów, co Menéndez Pidal tłumaczy jego niewolą w Kordobie, i pojawia się znów w roku 992, potwierdzając przekazanie włości w Tamarón ${ }^{13}$. Dwudziestoletnia luka jest jednak zbyt długa, by mogła pokrywać się z relacją z legendy, w której ojciec infantów spędził w kordobańskim więzieniu nie więcej niż rok ${ }^{14}$. Być może Gudestioz z roku 992 jest po prostu inną osobą, choć nie można oczywiście wykluczyć poetyckiej reinterpretacji chronologii zdarzeń, przy czym trzeba pamiętać, że uczestniczący w nich Gonzalo Gústioz niekoniecznie jest literackim odpowiednikiem historycznego Gonzala Gudestioza. W opinii Menéndeza Pidala koronnym dowodem na potwierdzenie tożsamości obydwu postaci miało być nadanie w 974 roku przez hrabiego Fernána Gonzáleza praw

10 R. Menéndez Pidal, La leyenda..., s. 13.

11 I. Álvarez Borge, Poder y relaciones sociales en Castilla en la Edad Media. Los territorios entre el Arlanzón y el Duero en los siglos X al XIV, Valladolid 1996, s. 77-80.

12 J. Escalona, Épica..., s. 125.

13 R. Menéndez Pidal, La leyenda..., s. 507-508.

${ }^{14}$ L. Chalon, L'histoire et l'épopée castillane du Moyen Âge. Le Cycle du Cid, le Cycle des comtes de Castille, Paris 1976, s. 482 i nn. 
do Salas de los Infantes oraz przywilejów (hiszp. fueros) Gonzalowi Gudestiozowi ${ }^{15}$. Jednak, jak zauważa Escalona, dokument przechowywany w Archiwum Miejskim Salas jest falsyfikatem, co zresztą stwierdził również jego wydawca ${ }^{16}$, więc nie może być brany pod uwagę, przynajmniej jako dowód potwierdzający słuszność omawianej w tym miejscu hipotezy ${ }^{17}$. Jego istnienie świadczy natomiast o popularności legendy jeszcze przed włączeniem jej w treść PCG, jeśli przyjąć wczesne datowanie dyplomu na XII wiek ${ }^{18}$, oraz o braku wiarygodnych materiałów źródłowych dostarczających niezbite dowody na historyczność tragedii infantów już w czasach stosunkowo nieodległych od opisywanych w legendzie wydarzeń.

Interpretacja falsyfikatu nie jest jedynym budzącym wątpliwości argumentem Menéndeza Pidala, ponieważ w równie beztroski sposób traktuje wzmiankę o żonie Gonzala Gudestioza, Prolinie, identyfikując ją jednoznacznie z Sanchą, matką infantów, a rozbieżność imion tłumaczy tym, że domniemana historyczna Sancha w aktach prawnych posługiwała się drugim imieniem. W historyczność Lambry hiszpański badacz po prostu wierzy ${ }^{19}$, chociaż w przekonujący sposób wywodzi imię postaci od łacińskiego Flamula (Flambla lub Flamla w dyplomach z X w. - Llambla w PCG) ${ }^{20}$. Natomiast komentując liczbę infantów, zauważa brak źródeł historycznych potwierdzających ich istnienie - prócz jednej niepewnej wzmianki, w której niejaki Gonzalo González, być może najmłodszy z braci, pojawia się jako

15 R. Menéndez Pidal, La leyenda..., s. 506-507.

16 Chodzi o publikację Luciano Serrano, Cartulario de San Pedro de Arlanza, Madrid 1925.

17 J. Escalona, Épica..., s. 125, p. 33.

${ }_{18}$ Ibidem. Álvarez Borge proponuje przesunięcie datowania dokumentu na połowę XIV wieku, co nie wpływa jednak na ocenę kontekstu jego powstania, to znaczy oczywisty brak źródeł potwierdzających istnienie bohaterów legendy.

$19, \ldots[. .$.$] creo que la Doña Lambra poética ha de ser de igual modo personaje$ histórico, por más que no la haya podido identificar [...]” („wierzę, że poetycka Pani Lambra musi być w taki sam sposób [jak Ruy Velázquez] postacią historyczną, chociaż nie mogłem jej zidentyfikować”), R. Menéndez Pidal, La leyenda..., s. 15.

20 Ibidem, s. 15, p. 2. 
sygnatariusz listu datowanego na 26 kwietnia 971 roku $^{21}$ - i zaznacza, że siódemka ma jedynie charakter symboliczny i należy do sfery wyobraźni poetyckiej. Poza tym poddaje słusznej krytyce rewelację o odkryciu przez burmistrza Salas w 1572 roku w kościele parafialnym pod wezwaniem Najświętszej Marii Panny skrzyni z ośmioma głowami, które miały należeć do siedmiu infantów i ich starego nauczyciela ${ }^{22}$. W tym miejscu warto przywołać komentarz Alana Deyermonda, który zauważa, że legenda o siedmiu infantach z Lary jest zapewne jedyną, która poprzedza kult domniemanego miejsca pochówku bohaterów poematu epickiego, ponieważ w przypadku tekstów zachowanych wiemy, że powstały jako rozwinięcie kultu istniejącego wcześniej (np. grób hrabiego Fernána Gonzáleza w San Pedro de Arlanza i Poema de Fernán González z XIII w.) ${ }^{23}$.

Najbardziej złożona wydaje się próba identyfikacji Ruya Velázqueza. Jego osobę początkowo wiązano z jednym ze zbuntowanych hrabiów galicyjskich, którzy nie chcąc się poddać władzy królów Leónu, uciekli się pod opiekę kalifów Kordoby, najpierw Al-Hakama II, a później Almanzora. Historia Compostelana ${ }^{24}$, łacińska kronika z XII wieku, oraz Chronicon Iriense ${ }^{25}$ (ok. 1120 r.) podają, że biskup Irii, Pelayo, syn Rudericusa Velasqui, został pozbawiony swojej funkcji przez króla

${ }^{21}$ Escalona zwraca tu uwagę, że imię oraz patronimik „Gonzalo González” były tak popularne w X wieku, że trudno mówić o identyfikacji. Przywołuje też dyplom z Cardeñii z 963 roku, w którym pojawiają się dwa podpisy: Didaca Gundissalbiza (Diego González, imię, które nosił najstarszy z infantów) i Guidessalba Gudistioza (J. Escalona, Épica..., s. 127-128). Eukene Lacarra podaje kolejne dwa imiona - Asur González i Ruy González - pochodzące z dokumentów z drugiej połowy $\mathrm{X}$ wieku, jednak zaznacza, że nie sposób dziś ustalić, czy wymienione wyżej osoby wiązało jakieś pokrewieństwo (E. Lacarra, Sobre la historicidad de la leyenda de los Siete Infantes de Lara, w: Historicist Essays on Hispano-Medieval Narrative in Memory of Roger W. Walker, ed. by B. Taylor, G. West, London 2005, s. 212).

22 R. Menéndez Pidal, La leyenda..., s. 12-13.

23 A. Deyermond, Historia y crítica de la literatura española. Edad Media, Barcelona 2001, s. 87.

${ }^{24}$ Historia Compostelana, ed. E. Falque, Madrid 1994, s. 74-75.

${ }_{25}$ Chronicon Iriense, w: Historia Compostelana donde se incluyen las pruebas del tomo precedente, con otras muchas noticias de Papas, Cardenales, Obispos, Concilios, 
Leónu i Galicji Bermuda II za udzielanie czynnego wsparcia innemu pretendentowi do galicyjskiego tronu, Ramirowi III ${ }^{26}$. W działaniach tych miał wspierać Pelaya jego ojciec, który z zemsty za pozbawienie syna władzy biskupiej sprowadził do Galicji wojska Almanzora. Zestawienie kronikarskich relacji z datami wskazuje jednak, że zarówno koronacja Bermuda II na króla (982 r.), jak i spustoszenie Santiago de Compostela przez Almanzora $\left(997\right.$ r. ${ }^{27}$ miały miejsce już po śmierci hrabiego Velázqueza ${ }^{28}$, więc podane w nich informacje należy traktować co najmniej z dużą rezerwą. Ślady po galicyjskim Ruyu Velázquezie zachowały się również w trzech źródłach arabskich ${ }^{29}$. Pierwsze to wspominane już annały kalifa Al-Hakama II, skopiowane przez Ibn Hayyana w kompilacji Muqtabis (X/XI w.), gdzie wymienia się liczne ambasady chrześcijańskich władców odwiedzające Kordobę, wśród których wzmiankowane jest poselstwo z 23 września 973 roku niejakiego Rodriga ibn Velasco, które uzyskało odpowiedź na przedstawioną sprawę, a na pożegnanie otrzymało stosowne podarki ${ }^{30}$. Tytuł, jakim

Reyes, Varones ilustres y en especial del primer Arzobispo de Santiago D. Diego Gelmirez, ed. H. Florez, Madrid 1765, s. 607.

${ }^{26}$ Należy pamiętać, że politycznie kroniki przedstawiają punkt widzenia szlachty galicyjskiej, zbuntowanej przeciwko Ramirowi III, prawowitemu władcy Leónu, Galicji i Kastylii, która obwołała w 981 roku Bermuda królem i koronowała go w Santiago de Compostela w roku następnym. García Fernández, mimo że blisko spokrewniony z Bermudem, nie uznał tej koronacji i dopiero po śmierci Ramira III w 985 roku podporządkował się władzy uzurpatora. Inne podejście prezentuje Amancio Isla Frez, który twierdzi, że obydwie kroniki dają wyraz reformie kluniackiej, a w lokalnej szlachcie widziały zagrożenie dla czystości i dobrego imienia Kościoła. A. Isla Frez, Ensayo de historiografía medieval. El Cronicón Iriense, „En la España medieval" 4 (1984), s. 415-416, 422-424.

${ }^{27}$ Menéndez Pidal, a za nim Escalona podają błędną datę rajdu na Santiago 986 rok. R. Menéndez Pidal, La leyenda..., s. 14, J. Escalona, Épica..., s. 122.

${ }^{28}$ Datę śmierci hrabiego Velázqueza określił Menéndez Pidal terminus ante quem na 978 rok na podstawie dokumentu, w którym biskup Pelayo wspomina o zgonie ojca. R. Menéndez Pidal, La leyenda..., s. 14. Datowanie potwierdził José-Luis Martín, Pelayo Rodríguez, obispo de Santiago, „Anuario de los estudios medievales" 2 (1965), s. 471, p. 34.

${ }^{29}$ J. Escalona, Épica..., s. 119-120.

${ }^{30}$ El califato de Córdoba..., s. 173-174. 
się określa Rodriga w annałach, to qumis, to jest hrabia, natomiast trudno dziś określić położenie jego włości, ponieważ jedyna zachowana kopia Muqtabis pochodzi z XIX wieku i zawiera liczne błędy ${ }^{31}$. Drugim źródłem jest historia uniwersalna Ibn Chalduna Kitāb al-'ibar (XIV w.), gdzie autor podaje informację o wizycie w Kordobie matki Ruya Velázqueza, która przybyła do kalifatu w roku 975 lub 976, aby prosić w imieniu syna o pokój ${ }^{32}$. Tę samą wiadomość cytuje siedemnastowieczna kronika Al-Maqariego Najh al-tib, przy czym zmienia kolejność datowania obydwu poselstw. W kronice Ibn Chalduna Velázquez określany jest jako al-qumis bi-l-qurb min Yilliqiya, co znaczy „najważniejszy z hrabiów najbliższej części Galicji”, czyli terenów graniczących w $\mathrm{X}$ wieku $\mathrm{z}$ kalifatem, a podlegających władzy królów Leónu ${ }^{33}$.Zatem zarówno kroniki chrześcijańskie, jak i muzułmańskie wspominają Rodriga Velázqueza galicyjskiego, który z pewnością nie posiadał włości w rejonie Lary ani nie był wasalem hrabiego Kastylii. Menéndez Pidal, zakładając, że główni bohaterowie legendy muszą być postaciami historycznymi, doszedł do wniosku, że panem Lary był zapewne jakiś inny Ruy Velázquez, którego ojca tradycja literacka zapamiętała jako rycerza walczącego u boku hrabiego Kastylii Fernána Gonzáleza $^{34}$. Zatem o ile galicyjski Velázquez jest dość dobrze znany historykom, o kastylijskim nie wiadomo nic pewnego. Można jedynie przyjąć, że pamięć o krytykowanym przez Chronicon Iriense oraz Historia Compostelana Rodrigu Velázquezie, zdradziecko paktującym z Almanzorem, przeniknęła do Kastylii i została twórczo wykorzystana w kreacji Ruya Velázqueza, bohatera legendy. Zwłaszcza że, jak zauważa Escalona ${ }^{35}$, gdyby Velázquez rzeczywiście pochodził z Lary,

${ }^{31}$ Zob. komentarz J. Escalony, Épica..., s. 120.

32 Ibidem, s. 120-121.

33 Ibn Jaldún, húab al-Ibar, ed. J. Sahada, Beirut 1981-1983, vol. 4, s. 187, za: J. Escalona, Épica..., s. 120-121.

${ }^{34}$ R. Menéndez Pidal, La leyenda..., s. 14-15. W pieśni Poema de Fernán González Ruy Velázquez bierze udział w dwóch bitwach pod Larą (w. 264-265) i pod Hacinas (w. 454-455).

${ }^{35}$ J. Escalona, Épica..., s. 123. 
należałby do rodziny hrabiów Kastylii, która się stamtąd wywodziła, czego nie potwierdzają żadne źródła $\mathrm{z}$ epoki.

Podsumowując, ani dokumenty pochodzące z kalifatu Kordoby, ani chrześcijańskie nie dowodzą historyczności wypadków opisanych w legendzie o siedmiu infantach z Lary. Ślady występujących w niej postaci są zbyt słabe, aby potwierdzały przeprowadzoną przez Menéndeza Pidala identyfikację, nie ma też pewności co do przedstawionego przez badacza datowania legendy. Zbieżność z epizodem dyplomatycznym z 974 roku nie jest wystarczająca, by umożliwić osadzenie dramatu infantów w tych właśnie czasach, nie zachowała się też oryginalna pieśń epicka, na podstawie której można by szukać wydarzeń będących jej źródłem.

\section{Warianty tekstu}

Zgodnie z koncepcją Menéndeza Pidala ewolucja Legendy o siedmiu infantach $z$ Lary przeszła przez trzy etapy, w czasie których powstawały na jej temat niezachowane do dzisiaj pieśni epickie (zob. il. 1).

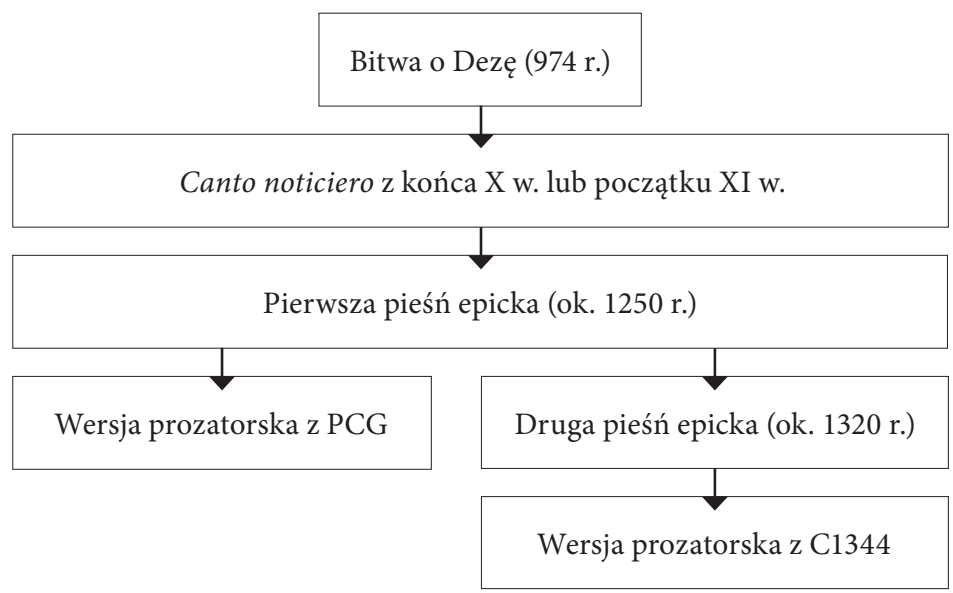

Il. 1. Schemat ewolucji legendy o siedmiu infantach z Lary według Menéndeza Pidala 
Najstarszą wersją jest zatem krótka pieśń epicka o charakterze informacyjnym, tak zwana canto noticiero, powstała jeszcze $\mathrm{w}$ wie$\mathrm{ku} X$, to jest współczesna opisywanym wydarzeniom ${ }^{36}$. Pieśń ta byłaby dziełem anonimowych poetów - żonglerów (hiszp. juglares), a przekazywana wyłącznie ustnie - miała podlegać zmianom charakterystycznym dla tego typu poezji. Około roku 1250 pierwotna wersja została uformowana $\mathrm{w}{ }^{\star}$ Pierwsza pieśń o siedmiu infantach z Lary, która posłużyła autorom Pierwszej kroniki powszechnej za podstawę prozyfikacji. Ponieważ między kronikami PCG i C1344 występują znaczne różnice w zawartości drugiej części legendy, to znaczy C1344 rozwija o nowe szczegóły wątki z PCG oraz dodaje nieobecne w niej rozwiązania narracyjne, takie jak zwiększenie roli Sanchy w zemście dokonanej przez Mudarrę czy rozbudowanie konfrontacji Mudarry z Ruyem Velázquezem, Menéndez Pidal doszedł do wniosku, że C1344 musi opierać się na innym źródle, czyli na kolejnej wersji legendy, nazwanej przez badacza ${ }^{\star}$ Druga pieśnią, której datowanie określił na około 1320 rok. Deyermond uzupełnił ten wywód, dodając, że formularny charakter zachowanych w kronikach wersów i ich podobieństwo kompozycyjne do struktury badanych przez Alberta B. Lorda i Milmana Parry'ego eposów jugosłowiańskich ${ }^{37}$ pozwala sądzić, że zaginiona ${ }^{\star}$ Pieśń... musiała należeć do najwcześniejszych kastylijskich pieśni epickich ${ }^{38}$. Tezy te nie są niestety weryfikowalne $\mathrm{z}$ braku materiału badawczego

36 R. Menéndez Pidal, La leyenda..., s. 3-4.

37 Parry i Lord, badając twórczość oralną poetów epickich, działających jeszcze w latach 50. XX wieku w Jugosławii, zauważyli, że posługują się oni charakterystycznymi formułami (wyrażeniami o stałej postaci, rytmice i metrum) do opisu postaci, miejsc czy wydarzeń. Formuły te, o archaicznych korzeniach, ułatwiały zapamiętanie pieśni, ale służyły również do tworzenia nowych kompozycji i były wielokrotnie wykorzystywane przez różnych artystów niezależnie od siebie. Podobną strukturę mają zarówno eposy homeryckie, jak i średniowieczne. Przykładem formuły jest powtarzający się w epice kastylijskiej pleonazm llorar de los ojos (dosłownie: płakać z oczu), pojawiający się w scenach silnych wzruszeń. Wyniki ich pracy opublikował A.B. Lord, Pieśniarz i jego opowieść, przeł. P. Majewski, Warszawa 2010.

38 A. Deyermond, Historia..., s. 87. 
i zamykają się w sferze domysłów. Jednak na ciągłość rozwoju tekstu w formie ustnej i jego przeobrażenia wskazuje podawane w niektórych rękopisach PCG podwójne określenie pochodzenia infantów: „de Salas” i „de Lara”" ${ }^{39}$, które potwierdza powszechną znajomość tekstu już w XIII wieku oraz jego wariantywność. Ponadto pojawiające się w kronikach odwołania do „historii” ${ }^{40}$, wspomniane przez Deyermonda specyficzne cechy języka oraz dająca się zauważyć obecność rymów w kronikarskiej prozie potwierdzają istnienie niezachowanego do naszych czasów poematu epickiego, skomponowanego najpóźniej w okresie, kiedy skryptorium Alfonsa X Mądrego zaczęło zbierać materiały do pierwszej kastylijskiej kroniki Hiszpanii, czyli przed 1270 rokiem.

Z wersji zachowanych do najważniejszych źródeł wykorzystywanych do badań nad legendą zalicza się dwa teksty: Pierwszą kronikę powszechna, którą omawiam w osobnym rozdziale, oraz Kronikę z 1344. Ta ostatnia zachowała się w dwóch redakcjach: pierwszej, będącej kastylijskim przekładem z zaginionego dziś portugalskiego oryginału, oraz drugiej, z około 1400 roku, przekazanej w dwóch wersjach językowych, kastylijskiej i portugalskiej. Odmienność zamieszczonej w C1344 wersji legendy ${ }^{41}$ wynika nie tylko ze wspomnianej wyżej specyfiki materiału stanowiącego podstawę kompilacji, ale również z zupełnie innego programu ideologicznego przyjętego przez autora. PCG we wszystkich swoich wariantach buduje podwaliny kastylijskiej

39 „Mas agora dexamos aqui de fablar del Rey don Ramiro. e diremos de los vij. jnfantes de Salas. Et otros les dizen de Lara”. („Lecz teraz nie będziemy więcej mówić o Królu Ramirze i powiemy o siedmiu infantach z Salas. A inni zwą ich z Lary"). Estoria de Espanna Digital, rękopis X-I-4, Biblioteca del Monasterio de San Lorenzo (El Escorial, Madrid), rozdz. 746, 2016, wydanie on-line: http://estoria. bham.ac.uk/edition/ (dostęp: 14.11.2019).

${ }^{40}$ Formuła segund dize la Estoria (wedle tego, co głosi historia) pojawia się w PCG kilka razy, a odwołanie do „historii”, nie zaś „pieśni”, występujące przy innych prozyfikacjach, może oznaczać, że skrybowie pracowali nie na oryginalnym tekście epickim, ale jego streszczeniu prozą.

${ }^{41}$ Zestawienie różnic podaję w tabeli poniżej. 
polityki imperialnej ${ }^{42}$, natomiast $\mathrm{C} 1344$ przyjmuje nieco inny punkt widzenia na przeszłość Półwyspu Iberyjskiego, ponieważ powstała poza dworem królewskim ${ }^{43}$. Uważa się, że autorem kroniki jest Pedro Alfonso, trzeci hrabia Barcelos i nieślubny syn Dionizego I, króla Portugalii, który spędził na wygnaniu w Kastylii trzy lata między 1317 a 1320 rokiem. Wtedy też nawiązał przyjaźń z Juanem Núñezem III de Lara, głową jednego z najpotężniejszych kastylijskich domów arystokratycznych, dzięki któremu uzyskał dostęp do oryginalnych dokumentów na temat historii rodu oraz dziejów Hiszpanii. Zanim Legenda o siedmiu infantach z Lary stała się częścią C1344, de Barcelos umieścił ją w napisanej po portugalsku księdze herbowej rodów szlacheckich Livro de Linhagens (ok. 1340 r.), chociaż w wersji dość okrojonej, ponieważ starał się przede wszystkim wykazać, że ród Lara wywodzi się od Mudarry i w ten sposób wiąże z dynastią władców Leónu ${ }^{44}$. Jak wskazuje Ingrid Vindel ${ }^{45}$, księga była jednym ze źródeł dla wariantu legendy z C1344, chociaż jedynie w zakresie koligacji rodzinnych występujących w niej bohaterów. Aby usunąć skojarzenie z Ruyem Velázquezem (który, przypomnijmy, w legendzie nosi tytuł pana Lary), relacja z C1344 przedstawia go w ciemnych barwach jako

${ }^{42} \mathrm{Na}$ temat polityki Alfonsa X Mądrego powstało wiele opracowań, w tym miejscu warto wspomnieć o monografii pod redakcją Georges'a Martina, analizującej pod tym względem kroniki alfonsyńskie: La historia alfonsí: el modelo y sus destinos, siglos XIII-XV, Madrid 2000.

${ }^{43}$ Kwestie autorstwa poszczególnych redakcji kroniki oraz znaczenie jej zawartości szczegółowo omawiają autorzy trzech jej współczesnych wydań: Diego Catalán, María Soledad de Andrés: Crónica General de España de 1344, ed. D. Catalán, M. Soledad de Andrés, Madrid 1971 (pierwsza część pierwszej redakcji); Luís Filipe Lindley Cintra: Crónica Geral de Espanha de 1344, ed. L.F. Lindley Cintra, vol. 1-4, Lisboa 1951-1990, (druga redakcja opracowana na podstawie źródeł portugalskich) oraz Ingrid Vindel: Crónica de 1344, edición y estudio (praca doktorska; pierwsza redakcja opracowana w całości), ed. I. Vindel, Bellaterra 2015, wydanie on-line: https://www.tdx.cat/bitstream/handle/10803/386537/invilde1. pdf? sequence=1 (dostęp: 14.11.2019).

${ }^{4}$ Wprowadzając Artigę Ramírez, córkę króla Leónu, jako babkę Mudarry. J. Escalona, Épica..., s. 154-156.

${ }^{45}$ Crónica de $1344 \ldots$, s. 217-219. 
zdrajcę, który utraciwszy poparcie Almanzora, buntuje się przeciwko własnemu seniorowi, hrabiemu Garcíi Fernándezowi. Bezdzietna śmierć Ruya Velázqueza przenosiła zatem prawa do Lary na jego siostrę Sanchę, i dalej na Mudarrę, co w konsekwencji pozwala jego „potomkom” chlubić się pochodzeniem od legendarnych bohaterów. Chociaż próby powiązania rodu de Lara z siedmioma infantami są wcześniejsze niż $\mathrm{C} 1344^{46}$, co tłumaczy podwójną toponimię z PCG, to nadbudowa wątków narracyjnych wokół postaci Sanchy i Mudarry ujawnia plan ideologiczny de Barcelosa, polegający na wywyższeniu rodu de Lara ponad inne kastylijskie rodziny szlacheckie. Powiązania autora $\mathrm{C} 1344 \mathrm{z}$ rodem Lara oraz bardzo rozbudowany w kronice wariant części drugiej legendy skłoniły Escalonę do postawienia dość rewolucyjnej hipotezy, w której neguje istnienie ${ }^{\star}$ Drugiej pieśni. Uważa on, że zarówno PCG, jak i C1344 korzystają z tego samego źródła, tyle że PCG je streszcza, zaś C1344 oddaje ze wszystkimi szczegółami. Skrybowie pracujący nad PCG mieli, według Escalony, otrzymać z klasztoru San Pedro de Arlanza jedynie wyciąg prozą z ${ }^{\star}$ Pierwszej pieśni, stąd duże skróty, natomiast de Barcelos korzystał z biblioteki rodu de Lara, w której mógł się znajdować kompletny poemat, zatem C1344 byłaby bliższa oryginalnej wersji legendy, mimo że powstała później".

Najważniejsze różnice między wariantami legendy w obydwu kronikach przedstawiają się następująco:

\section{Pierwsza kronika powszechna}

\section{Kronika $z 1344$}

Część pierwsza w obydwu kronikach nie wykazuje większych różnic, które pojawiają się dopiero w części drugiej, to jest od sceny ścięcia infantów na polu bitwy Ruy Velázquez wraca do Ruy Velázquez wraca do swoich włości w Bilveswoich włości w Bilvestre; stre; głowy odwozi do Kordoby Alicante, jeden Maurowie wysyłają głowy $\mathrm{z}$ dowódców walczących z chrześcijanami na podo Kordoby lach Almenaru

\footnotetext{
46 J. Escalona, Épica..., s. 162.

47 Ibidem, s. 163-168.
} 


\begin{tabular}{|c|c|}
\hline $\begin{array}{l}\text { Pierwsza kronika } \\
\text { powszechna }\end{array}$ & Kronika z 1344 \\
\hline & $\begin{array}{l}\text { Po drodze Alicante uświadamia sobie ogromne stra- } \\
\text { ty w ludziach, jakie poniosło wojsko muzułmańskie, } \\
\text { i wysyła list do Ruya Velázqueza, w którym wimie- } \\
\text { niu własnym oraz Almanzora wyzywa szlachcica } \\
\text { na pojedynek oraz nazywa zdrajcą. Ruy Velázqu- } \\
\text { ez żałuje swoich czynów, ale utraciwszy szacunek } \\
\text { zarówno muzułmanów, jak i chrześcijan, podno- } \\
\text { si bunt przeciwko hrabiemu Kastylii i umacnia się } \\
\text { w zamkach, które od niego otrzymał w lenno }\end{array}$ \\
\hline & $\begin{array}{l}\text { Alicante przybywa do Kordoby w piątek, w wigilię } \\
\text { św. Cypriana (13 IX) }\end{array}$ \\
\hline $\begin{array}{l}\text { Almanzor prosi Gonzala Gú- } \\
\text { stioza, aby zidentyfikował } \\
\text { głowy poległych }\end{array}$ & $\begin{array}{l}\text { Almanzor prosi Gonzala Gústioza, aby zidentyfi- } \\
\text { kował głowy poległych }\end{array}$ \\
\hline $\begin{array}{l}\text { Kiedy Gonzalo Gústioz roz- } \\
\text { poznaje głowy synów i ich } \\
\text { opiekuna, pada zemdlony }\end{array}$ & $\begin{array}{l}\text { Kiedy Gonzalo Gústioz rozpoznaje głowy synów } \\
\text { i ich opiekuna, w napadzie szału chwyta za miecz } \\
\text { i ścina trzech mauryjskich strażników, a następnie } \\
\text { wybiega na ulicę, gdzie zabija napotkanych ludzi. } \\
\text { Almanzor nakazuje wszystkim schować się w do- } \\
\text { mach i nie powstrzymuje Gústioza }\end{array}$ \\
\hline $\begin{array}{l}\text { Po odzyskaniu przytomno- } \\
\text { ści wygłasza lament żałobny } \\
\text { nad każdą z głów po kolei, } \\
\text { którego PCG nie cytuje, nie } \\
\text { wymienia też imion infan- } \\
\text { tów oprócz najstarszego Die- } \\
\text { ga i najmłodszego Gonzala }\end{array}$ & $\begin{array}{l}\text { Gdy szał mija, Gústioz wraca do pałacu i wygłasza } \\
\text { lament żałobny nad każdą z głów, poczynając od } \\
\text { Nuña Salida, a następnie wymienia synów w po- } \\
\text { rządku od najstarszego. Wylicza również ich naj- } \\
\text { większe zalety: Diego González, jako pierworodny, } \\
\text { był ukochanym synem ojca i niósł sztandar hrabie- } \\
\text { go Garcíi Fernándeza w bitwie pod Vado de Casca- } \\
\text { jar, za co otrzymał od seniora posiadłość w Cara- } \\
\text { zo. Martín był doskonałym graczem w tryktraka } \\
\text { i świetnym mówcą, Suero zaś mistrzem w polowa- } \\
\text { niach z ptakami. Fernando był biegły w łowach na } \\
\text { grubego zwierza, a Ruy stanowił przykład wier- } \\
\text { nego i dobrego rycerza. Gustio był prawdomówny } \\
\text { i zręczny w mieczu, natomiast najmłodszy Gonza- } \\
\text { lo - ukochany przez matkę i pełen cnót rycerskich }\end{array}$ \\
\hline $\begin{array}{l}\text { W przypływie złości Gústioz } \\
\text { zabija mieczem siedmiu } \\
\text { mauryjskich dowódców }\end{array}$ & \\
\hline
\end{tabular}




\begin{tabular}{|c|c|}
\hline $\begin{array}{c}\text { Pierwsza kronika } \\
\text { powszechna }\end{array}$ & Kronika $z 1344$ \\
\hline $\begin{array}{l}\text { Mauryjka, która opiekowa- } \\
\text { ła się Gústiozem w niewoli } \\
\text { i zaszła z nim w ciążę, pocie- } \\
\text { sza go, opowiadając o śmier- } \\
\text { ci swoich dwunastu synów } \\
\text { w bitwie }\end{array}$ & $\begin{array}{l}\text { Almanzor, poruszony lamentem Gústioza, naka- } \\
\text { zuje siostrze, aby się nim zajęła, na co ta zgadza się } \\
\text { niechętnie, powodowana strachem. Wyraża swo- } \\
\text { ją nienawiść do chrześcijan, a następnie opowia- } \\
\text { da Gústiozowi zmyśloną historię o tym, jak straci- } \\
\text { ła siedmiu synów w bitwie. Dodaje, że Gústioz jest } \\
\text { jeszcze młody i może spłodzić potomstwo, które go } \\
\text { pomści. Gústioz rozumie opowieść siostry Alman- } \\
\text { zora dosłownie i gwałci ją, aby urodziła mu syna }\end{array}$ \\
\hline \multirow{2}{*}{$\begin{array}{l}\text { Almanzor zwalnia Gústio- } \\
\text { za z więzienia i wyprawia do } \\
\text { Salas. Przy pożegnaniu Mau- } \\
\text { ryjka wyjawia, że jest ciężar- } \\
\text { na, i Gústioz nakazuje, by } \\
\text { wychowała dziecko, a jeśli } \\
\text { urodzi się chłopiec, wysła- } \\
\text { ła go do Salas, gdy doroś- } \\
\text { nie. Zostawia połówkę złote- } \\
\text { go pierścienia, dzięki której } \\
\text { rozpozna syna w przyszłości }\end{array}$} & $\begin{array}{l}\text { Almanzor zwalnia Gústioza z więzienia i wypra- } \\
\text { wia do Salas. Przy pożegnaniu Mauryjka wyjawia, } \\
\text { że jest w ciąży, i Gústioz nakazuje, by wychowa- } \\
\text { ła dziecko. Jeśli urodzi się dziewczynka, prosi, by } \\
\text { Almanzor wydał ją za mąż, a jeśli chłopiec, by wy- } \\
\text { słała go do Salas, gdy dorośnie. Zostawia połów- } \\
\text { kę złotego pierścienia, dzięki której rozpozna syna } \\
\text { w przyszłości }\end{array}$ \\
\hline & $\begin{array}{l}\text { Po powrocie Gústioza do Salas i pierwszej radości } \\
\text { następuje wielka żałoba, w której uczestniczy rów- } \\
\text { nież hrabia García Fernández. Hrabia nie może sam } \\
\text { wymierzyć sprawiedliwości, ponieważ zbuntowany } \\
\text { Ruy Velázquez bez litości najeżdża ziemie Kastylii. } \\
\text { Gústiozowi pozostają jedynie włości w Salas, gdzie } \\
\text { przez osiemnaście lat rozpacza nad swoim nieszczęś- } \\
\text { ciem. Od ciągłego płaczu traci wzrok }\end{array}$ \\
\hline $\begin{array}{l}\text { Po wyjeździe Gonzala Gú- } \\
\text { stioza z Kordoby Mauryjka } \\
\text { rodzi chłopca, któremu Al- } \\
\text { manzor nadaje imię Mudar- } \\
\text { ra González }\end{array}$ & $\begin{array}{l}\text { Po wyjeździe Gonzala Gústioza z Kordoby Mauryj- } \\
\text { ka rodzi chłopca, któremu Almanzor nadaje imię } \\
\text { Mudarra González }\end{array}$ \\
\hline $\begin{array}{l}\text { W } 968 \text { roku, kiedy Mudarra } \\
\text { kończy } 10 \text { lat, zostaje paso- } \\
\text { wany na rycerza i otrzymu- } \\
\text { je } 200 \text { giermków do swojej } \\
\text { drużyny }\end{array}$ & \\
\hline
\end{tabular}




\begin{tabular}{|c|c|}
\hline $\begin{array}{c}\text { Pierwsza kronika } \\
\text { powszechna }\end{array}$ & Kronika $z 1344$ \\
\hline \multirow[t]{3}{*}{$\begin{array}{l}\text { Gdy Mudarra osiąga dojrza- } \\
\text { łość, dowiaduje się o swo- } \\
\text { ich braciach i wyrusza do } \\
\text { Salas. Od matki otrzymuje } \\
\text { połówkę pierścienia, a od } \\
\text { Almanzora przebywających } \\
\text { w niewoli chrześcijańskich } \\
\text { rycerzy }\end{array}$} & $\begin{array}{l}\text { Gdy Mudarra wygrywa w szachy z mauryjskim } \\
\text { królem Segurą, ten wykpiwa go jako bękarta, za co } \\
\text { Mudarra zabija go szachownicą. Następnie domaga } \\
\text { się od matki wyjaśnień, zabiera połówkę pierście- } \\
\text { nia i wyrusza do Salas. Almanzor oddaje do jego } \\
\text { drużyny } 300 \text { przebywających w niewoli chrześci- } \\
\text { jańskich rycerzy }\end{array}$ \\
\hline & $\begin{array}{l}\text { Po drodze do Salas Mudarra zatrzymuje się w bo- } \\
\text { gatym i dobrze zaopatrzonym Bilvestre, należącym } \\
\text { do Ruya Velázqueza. Na żądanie zapłaty za gościnę } \\
\text { zabija majordoma, pali Bilvestre i przenosi się do } \\
\text { Veli. Następnego dnia przybywa do Salas }\end{array}$ \\
\hline & $\begin{array}{l}\text { Sanchy, matce infantów, śni się sen, w którym wi- } \\
\text { dzi, jak przybyły z Kordoby jastrząb wyrywa Ruy- } \\
\text { owi Velázquezowi ramię, a Sancha pije krew zdraj- } \\
\text { cy. Gonzalo Gústioz rozpoznaje w śnie zapowiedź } \\
\text { przybycia Mudarry }\end{array}$ \\
\hline \multirow{2}{*}{$\begin{array}{l}\text { W Salas Mudarra spotyka } \\
\text { Gonzala Gústioza, któremu } \\
\text { wyjawia swoją tożsamość. } \\
\text { Zostaje radośnie przyjęty } \\
\text { przez domowników, a na- } \\
\text { stępnie ogłasza, że zamie- } \\
\text { rza pomścić braci }\end{array}$} & $\begin{array}{l}\text { W Salas Mudarra odkrywa, że pałac ojca popadł } \\
\text { w ruinę, a Gonzalo Gústioz nie chce go przyjąć } \\
\text { w obawie, że wyda się cudzołóstwo, którego do- } \\
\text { puścił się w Kordobie }\end{array}$ \\
\hline & $\begin{array}{l}\text { Mudarra znajduje w kościele głowy przyrodnich } \\
\text { braci, na które poprzysięga zemstę. Następnie wy- } \\
\text { jawia swoją tożsamość Gonzalowi Gústiozowi i San- } \\
\text { chy, ale ojciec się go wypiera. Mudarra tłumaczy, } \\
\text { że nie przybył, aby przejąć ubogie mienie rodzin- } \\
\text { ne, ale by pomścić braci. Sancha zauważa niezwykłe } \\
\text { podobieństwo fizyczne między Mudarrą a Gonza- } \\
\text { lem Gonzálezem i prosi męża, aby uznał syna. Kie- } \\
\text { dy Mudarra pokazuje połówkę pierścienia, która } \\
\text { w cudowny sposób łączy się z połówką ojca, wieść } \\
\text { o przybyciu przyrodniego brata infantów zosta- } \\
\text { je rozgłoszona po okolicy. Mudarra najeżdża Bar- } \\
\text { badillo, własność Lambry, i je niszczy }\end{array}$ \\
\hline
\end{tabular}




\begin{tabular}{|c|c|}
\hline $\begin{array}{c}\text { Pierwsza kronika } \\
\text { powszechna }\end{array}$ & Kronika z 1344 \\
\hline & $\begin{array}{l}\text { Mudarra zostaje przedstawiony hrabiemu Kastylii } \\
\text { Garcíi Fernándezowi, który również zauważa po- } \\
\text { dobieństwo do najmłodszego z infantów. Następ- } \\
\text { nego dnia Mudarra zostaje ochrzczony w katedrze } \\
\text { w Burgos, a Sancha przysposabia go jako swojego } \\
\text { syna i czyni spadkobiercą należących do niej wło- } \\
\text { ści. García Fernández pasuje Mudarrę na rycerza } \\
\text { i mianuje zarządcą wszystkich swoich ziem }\end{array}$ \\
\hline \multirow[t]{2}{*}{$\begin{array}{l}\text { Mudarra zostaje przedsta- } \\
\text { wiony hrabiemu Kastylii } \\
\text { Garcíi Fernándezowi i wy- } \\
\text { zywa Ruya Velázqueza na } \\
\text { pojedynek. Hrabia ogła- } \\
\text { sza trzydniowe zawieszenie } \\
\text { broni, które Velázquez wy- } \\
\text { korzystuje, aby potajemnie } \\
\text { uciec w nocy do Barbadil- } \\
\text { lo. Mudarra dowiaduje się } \\
\text { o planach Velázqueza, cze- } \\
\text { ka na niego na drodze i tam } \\
\text { go zabija }\end{array}$} & $\begin{array}{l}\text { Ruy Velázquez ukrywa się w zamku Amaya, a gdy } \\
\text { Mudarra i hrabia podchodzą pod niego z wojska- } \\
\text { mi, ucieka. Mudarra ściga Velázqueza od zamku do } \\
\text { zamku przez Castrojeriz, Saldañę, Monzón, Torre } \\
\text { de Momojón, Dueñas, Tariego, Cabezón, Arandę } \\
\text { i Clunię. Podczas ucieczki do miejscowości Espe- } \\
\text { ja Mudarra dościga zbiega i wyzywa go na pojedy- } \\
\text { nek, który zwycięża. Gonzalo Gústioz chce zabrać } \\
\text { rannego Velázqueza do Salas, aby Sancha mogła } \\
\text { wypić jego krew, tak jak to zobaczyła w proroczym } \\
\text { śnie, lecz Mudarra się nie zgadza i zabiera więźnia } \\
\text { do Bilvestre }\end{array}$ \\
\hline & $\begin{array}{l}\text { W Bilvestre Mudarra po raz kolejny nie zgadza się, } \\
\text { by Sancha wypiła krew wroga, pozwala natomiast } \\
\text { na przywiązanie Velázqueza do drewnianej wieży, } \\
\text { by stał się celem dla włóczni wszystkich tych, któ- } \\
\text { rych krewni stracili przez niego życie. Na koniec } \\
\text { Velázquez zostaje ukamienowany }\end{array}$ \\
\hline $\begin{array}{l}\text { Aby zemścić się na Lambrze, } \\
\text { Mudarra czeka na śmierć } \\
\text { hrabiego Kastylii, ponieważ } \\
\text { jest ona jego bliską krew- } \\
\text { ną. Następnie każe ją spalić }\end{array}$ & $\begin{array}{l}\text { Lambra prosi o pomoc Garcíę Fernándeza, której } \\
\text { ten odmawia. Lambra do śmierci hrabiego błąka się } \\
\text { sama z jedną tylko służącą, a później ginie na roz- } \\
\text { kaz Mudarry taką samą śmiercią jak Ruy Velázquez }\end{array}$ \\
\hline
\end{tabular}




\section{Pierwsza kronika powszechna (Primera crónica general): opis źródła}

Kronika, która przekazała pierwszą znaną wersję Legendy o siedmiu infantach $z$ Lary, powstała jako jeden z dwóch wielkich projektów historiograficznych na dworze władcy Kastylii i Leónu Alfonsa X Mądrego (1221-1284). Była to Estoria de España, bo tak oryginalnie brzmiał tytuł Pierwszej kroniki powszechnej ${ }^{48}$. Nowy tytuł, obecnie dużo powszechniej używany, nadał jej pierwszy wydawca, Ramón Menéndez Pidal, który opublikował tekst kroniki w 1906 roku $\left({ }^{2} 1955,{ }^{3} 1977\right)$. PCG powstała w skryptorium królewskim jako kompilacja tekstów wcześniejszych i jest pierwszą oryginalną historią Hiszpanii napisaną w języku kastylijskim, to znaczy niebędącą przekładem z łaciny. Za życia króla powstały dwie redakcje kroniki ${ }^{49}$ (niezachowane w pełnych kodeksach), tak zwana wersja pierwotna (hiszp. versión primitiva), spisana w latach 1270-1274 i obejmująca czasy od Mojżesza po panowanie ostatniego władcy Leónu, Bermuda III, oraz druga, zwana wersją krytyczną (hiszp. versión crítica), z lat 1282-1284, obejmująca okres od czasów gockich po śmierć Ferdynanda II z Leónu. Uważa się, że obydwie redakcje PCG opierają się na wspólnym źródle (archetypie), z którego je kopiowano i uzupełniano. Wszystkie rękopisy kroniki powstałe za życia Alfonsa X Mądrego nazywa się „kronikami alfonsyńskimi”, w liczbie mnogiej, ponieważ zachowane manuskrypty różnią się między sobą, choćby z tego względu, że były kopiowane, skracane lub uzupełniane w tym samym czasie przez różnych skrybów. Jednak termin ten często używany jest w dużo szerszym znaczeniu, obejmującym również wszystkie kroniki powstałe po śmierci władcy,

48 Drugim projektem była monumentalna historia świata Grande e general estoria.

49 Opis PCG na podstawie monografii Inés Fernández-Ordóñez, Las Estorias de Alfonso el Sabio, Madrid 1992, oraz eadem, La transmisión textual de la "Estoria de España" y de las principales "Crónicas" de ella derivadas, w: Alfonso X el Sabio y las crónicas de España, al cuidado I. Fernández-Ordóñez et al., Valladolid 2000, s. 219-260. 
a bazujące na pierwszej lub drugiej redakcji PCG, mimo że właściwszym określeniem byłoby „kroniki postalfonsyńskie”.

W sumie zachowało się 37 manuskryptów zawierających różne warianty PCG, opracowywane na podstawie pierwszej lub drugiej redakcji. Natomiast do kronik postalfonsyńskich należą: Versión amplificada de 1289 (Wersja poszerzona z 1289), Crónica abreviada de don Juan Manuel (ok. 1320-1325; Skrócona kronika Juana Manuela), Crónica de Castilla (przed 1295 r.; Kronika Kastylii), Refundición de la Crónica de 1344 z ok. 1400 roku (Adaptacja Kroniki z 1344 r.), Crónica general de España z 1404 roku (Kronika powszechna Hiszpanii) i Repertorio de Príncipes de España Pedra de Escavias (1468-1469; Poczet Książąt Hiszpanii). Niektóre z nich zostały w stosunku do alfonsyńskiego oryginału znacznie poszerzone (Versión amplificada), skrócone (Crónica abreviada oraz Repertorio), inne zaś przetłumaczone na język galicyjski (Crónica general de España z 1404 r.) lub portugalski (Refundición de la Crónica de 1344 z ok. 1400 r.).

Rękopisy pierwszej redakcji, czyli te powielające w całości lub w części versión primitiva, dzieli się z kolei na dwie grupy: te, które bazują na kodeksie $\mathrm{E}_{1}$ (rkps Y-I-2, Biblioteca del Monasterio de San Lorenzo, El Escorial, Madryt), pochodzącym z królewskiego skryptorium, zaliczane są do wersji królewskiej (hiszp. versión regia), te zaś, które korzystają z niezachowanego źródła podstawowego, czyli wzmiankowanego wcześniej archetypu, określa się mianem wersji prostej (hiszp. versión vulgar). Cechą charakterystyczną tej ostatniej grupy jest znikoma liczba zmian i poprawek wprowadzanych przez kopistów do powielanego źródła. Rękopisów drugiej redakcji nie dzieli się na grupy, a za najpełniej reprezentujący tę wersję manuskrypt uważa się czternastowieczny kodeks oznaczony skrótem Ss (rkps 40, Biblioteca de la Caja de Ahorros, Salamanca), który zawiera versión crítica na kartach 2-264a i Crónica de Castilla oraz Crónica particular de San Fernando na kartach 264va-325ra. Do rodziny kronik powstałych na bazie versión crítica należy między innymi Crónica de veinte reyes, której fragmenty wykorzystywane są przez współczesnych wydawców do uzupełniania brakujących fragmentów 
dwóch pieśni epickich: Pieśni o Cydzie (Cantar de Mio Cid) i Poema de Fernán González (Pieśni o Fernánie Gonzálezie).

Najstarsza znana wersja Legendy o siedmiu infantach $z$ Lary znajduje się w wersji nazywanej Crónica lub Versión retóricamente amplificada de 1289, sporządzonej po śmierci Alfonsa X Mądrego na zlecenie jego syna Sancha IV Odważnego. Podstawowym źródłem do prac nad Versión amplificada był rękopis versión primitiva, rozpoczynający narrację od buntu Ramira I, późniejszego króla Asturii (835 r.), a kończący ją zdobyciem Kordoby przez Ferdynanda III Świętego (1236 r.). Tekst pierwszej redakcji rozszerzono o glosy, wstawki retoryczne, uzupełnienia zaczerpnięte z kronik łacińskich De rebus Hispaniae Rodriga Jiméneza de Rada, Chronicon mundi Lucasa de Tuy oraz Chronica Adefonsi Imperatoris, a także pieśni epickie, takie jak zaginiona dziś ${ }^{*}$ Pieśń o siedmiu infantach $z$ Lary. Zideologicznego punktu widzenia Versión amplificada oddala się od forsowanej przez Alfonsa X Mądrego wizji polityki imperialnej, co przejawia się między innymi wyniesieniem arystokracji i kleru do rangi elity politycznej królestwa, której obowiązkiem jest wspieranie władcy. Oryginalny rękopis Versión amplificada, spisany w XIII wieku, został za panowania Alfonsa XI (1312-1350) częściowo włączony do manuskryptu $\mathrm{E}_{2}$ (rkps X-I-4, Biblioteca del Monasterio de San Lorenzo, El Escorial, Madryt) i w tej postaci stał się podstawowym źródłem dla Kroniki z 1344 hrabiego Pedra Alfonsa de Barcelos i galicyjskiej Crónica general de España. Ponadto to właśnie rękopis $\mathrm{E}_{2}$ został opublikowany przez Menéndeza Pidala jako Primera Crónica General de España i jest podstawą niniejszego przekładu na język polski. 


\title{
Legenda o siedmiu infantach $z$ Lary (Leyenda de los siete Infantes de Lara) - przekład i opracowanie Rozalia Sasor
}

\begin{abstract}
$[736]^{50}$ Rozdział o tym, jak Ruy Velázquez ${ }^{51} \mathrm{z}$ Lary ${ }^{52}$ zranił swego siostrzeńca Gonzala Gonzáleza ${ }^{53}$, a siostrzeniec takoż jego, i o tym, jak hrabia García Fernández ${ }^{54}$ doprowadził między nimi do zgody ${ }^{55}$
\end{abstract}

W dwudziestym trzecim roku panowania króla Ramira, to jest w roku 997 albo w roku 959 od Wcielenia Pańskiego ${ }^{56}$, albo w dwudziestym

${ }^{50} \mathrm{~W}$ nawiasach kwadratowych podaję numery rozdziałów za PCG, z których pochodzi relacja o siedmiu infantach. Korzystam z wydań Primera Crónica General de España, ed. R. Menéndez Pidal, vol. 2, 3a ed., Madrid 1977, rozdz. 736-743 i 751, przedruk w: C. Alvar, M. Alvar, Épica medieval española, Madrid 1997, oraz Estoria de Espanna Digital, on-line 2016: http://estoria.bham.ac.uk/edition/ (dostęp: 14.11.2019).

51 Ponieważ we współczesnych opracowaniach na temat legendy o siedmiu infantach badacze posługują się wyłącznie uwspółcześnionym zapisem imion, patronimików bohaterów oraz nazw miejscowych, podaję je w takiej postaci również w niniejszym przekładzie. Formy oryginalne, pochodzące z Pierwszej kroniki powszechnej, w transkrypcji Menéndeza Pidala (dalej tMP), przytaczam jedynie przy pierwszym pojawieniu się danej nazwy i tylko jeśli znacznie różnią się od form współczesnych, tu: Roy Blásquez. Próby identyfikacji Ruya Velázqueza jako postaci historycznej omawiam we wstępie do niniejszego artykułu.

${ }^{52}$ Hiszp. alfoz de Lara. W średniowiecznej Kastylii terminem alfoz określano tereny rolnicze należące do grodu, które w czasach późniejszych zostały przekształcone, wraz z grodem, w samodzielną jednostkę administracyjno-prawną, to jest gminę (hiszp. municipio).

${ }^{53}$ Wzmianki w dokumentach z epoki świadczą o historyczności postaci Gonzala Gonzáleza, brata Diega, jednak jej identyfikacja z postacią z legendy jest niemożliwa, zob. wstęp do artykułu.

54 Postać historyczna, hrabia Kastylii w latach 970-995, syn Fernána Gonzáleza.

${ }^{55}$ Kronika $z 1344$ rozpoczyna relację od ataku Garcíi Fernándeza na Zamorę i jej oblężenia, w którym Ruy Velázquez bierze udział po stronie hrabiego wraz ze swoją drużyną złożoną z 300 rycerzy. Za udzieloną pomoc otrzymuje za żonę panią Lambrę, kuzynkę Garcíi Fernándeza. Crónica de 1344..., rozdz. CCXLV, s. 361.

56 Przesunięcie datowania o 38 lat wstecz odpowiada tak zwanej erze hiszpańskiej, to jest systemowi obliczania dat wprowadzonemu przez Wizygotów, którym 
szóstym panowania Ottona, cesarza rzymskiego, zdarzyło się wówczas, że pewien wielki pan, urodzony w Larze, który zwał się Ruy Velázquez, ożenił się z panią wielkiego rodu, urodzoną w Burebie ${ }^{57}$, siostrą cioteczną hrabiego Garcíi Fernándeza, która zwała się Lamb$\mathrm{ra}^{58}$. I ów Ruy Velázquez był panem na Bilvestre ${ }^{59}$ i miał siostrę, bardzo zacną panią, pełną wszelkich zalet i obyczajną, a zwała się Sancha, i wydano ją za zacnego pana Gonzala Gústioza, który był z Salas, i mieli siedmiu synów, których zwano siedmioma infantami z Sa$\operatorname{las}^{60}$. A wychował ich, wszystkich siedmiu, pewien bardzo zacny rycerz, który zwał się Nuño Salido ${ }^{61}$ i który wyuczył ich wszystkich zacnych sztuk, i przysposobił, by wszyscy przyjęli pas rycerski jednego dnia, a pasował ich hrabia García Fernández. Ów Ruy Velázquez, o którym mówiliśmy, kiedy żenił się z panią Lambrą, urządził wesele w mieście Burgos ${ }^{62}$ i zaprosił wszystkich swych przyjaciół z rozmaitych ziem: z Galicji, z Leónu, z Portugalii, z Estremadury, z Gaskonii, z Aragonii, z Nawarry, i zaprosił jeszcze wszystkich z Bureby i z całej Kastylii, i przybyło tam nadto mnóstwo innych ludzi. I był na owym weselu pan Gonzalo Gústioz z panią Sanchą, swoją żoną, i ze swoimi siedmioma synami, i z panem Nuñem Salidem, owym piastunem, który ich wychował. Wesele trwało pięć tygodni ${ }^{63}$, a towarzyszyło

chrześcijańskie królestwa z północy Półwyspu Iberyjskiego posługiwały się również po inwazji arabskiej aż do XV wieku. Ponadto, zgodnie z rachubą roku zwaną „stylem zwiastowania" (hiszp. año de la encarnación del Señor), rok rozpoczynał się 25 marca.

${ }^{57}$ tMP: Burueva. Wszystkie toponimy pojawiające się w legendzie odnoszą się do rzeczywistych miejscowości istniejących również w czasach współczesnych.

${ }^{58}$ tMP: donna Llambla. Historyczność tej postaci nie została potwierdzona.

${ }^{59}$ tMP: Biluestre.

${ }^{60}$ Salas, czyli rejon, z którego - zgodnie z tradycją - pochodzili infanci, został później zastąpiony toponimem Lara, aby wykazać pochodzenie kastylijskiego rodu arystokratycznego de Lara od Mudarry. Dlatego oryginalną nazwę „de Salas” opatrywano często aktualizującymi glosami.

${ }^{61}$ tMP: Munno Salido.

${ }^{62}$ Stolica hrabstwa Kastylii.

${ }^{63}$ Długość zabawy weselnej świadczyła o zamożności i prestiżu gospodarzy, jednak wydaje się, że 5 tygodni to licentia poetica. Dla porównania w Pieśni o Cydzie wesele córek Cyda trwało 15 dni (Cantar de Mio Cid, ed. A. Montaner, Barcelona 
mu zabaw bez liku, i tak: rzucano do wieży ${ }^{64}$, były bohurty ${ }^{65}$ i gonienie byków, gra w tryktraka i w szachy, a także wielu żonglerów ${ }^{66}$. I rozdali podczas owego wesela hrabia García Fernández i wszyscy inni wielcy panowie wiele bogactw i dużo podarków. A na tydzień przed zakończeniem wesela nakazał Ruy Velázquez wznieść bardzo wysoką wieżę na piaskach przy rzece i kazał rozgłosić, że temu, kto ją zwali, da piękną nagrodę. Rycerze, którzy mieli się za dobrych włóczników, wszyscy tam przybyli, lecz chociaż się wysilali srodze, nie mogli trafić ani w szczyt wieży, ani jej dosięgnąć. Gdy to zobaczył Álvar Sánchez, kuzyn pani Lambry, dosiadł wierzchowca i też pojechał rzucać do owej wieży, i trafił w nią z taką siłą, że aż

1993, w. 2251, s. 236), a 30 w romancy Yo me estando en Valencia (R. Menéndez Pidal, La leyenda..., s. 5), zaś wesele Aleksandra Wielkiego z Roksaną w Libro de Alexandre - 15 dni (Libro de Alexandre, ed. J. Caña, Madrid 2013, cuad. 1961, s. 469).

${ }^{64}$ Wieża lub inna podobna konstrukcja szkieletowa wykonana $\mathrm{z}$ drewna (hiszp. tablado) stanowiła cel w grze w wieżę, w której rycerze starali się przewrócić lub rozbić budowlę, rzucając w nią włócznią. Gra należała do popularnych rozrywek rycerstwa, wspomina się o niej również w Pieśni o Cydzie przy okazji zaślubin córek Cyda, Elviry i Sol (w. 2249-2250): „e al otro día fizo mio Çid fincar siete tablados: / antes que entrasen a yantar todos los crebantaron" (Cantar de Mio Cid, s. 236); w przekładzie A.L. Czerny: „Nazajutrz Cyd ustawić kazał drewniane bołdy, / Nim dzwoniono na obiad, został rząd powalony" (Pieśń o Cydzie, przeł. A.L. Czerny, Kraków 2003, s. 82). Do wież rzucano również podczas wesela Fernána Gonzáleza z Sanchą (Poema de Fernán González, ed. J. Victorio, Madrid 2010, cuad. 689, s. 167) oraz w trakcie zabaw zorganizowanych z okazji ślubu Aleksandra Wielkiego (Libro de Alexandre, cuad. 1961, s. 469).

${ }^{65}$ Bohurty również należały do rozrywek zarezerwowanych wyłącznie dla rycerstwa i polegały na organizowaniu na wydzielonym terenie potyczki na tępe włócznie.

${ }^{66}$ Rozrywki zaoferowane gościom Lambry i Ruya Velázqueza odtwarza Poema de Fernán González w planie zabaw urządzanych podczas wesela hrabiego: „Alançavan tablados todos los cavalleros / a tablas e escaques jugan los escuderos / dotra parte matavan los toros los monteros / avie y muchas çituals e muchos de violeros” („rzucali do wież wszyscy rycerze / w tryktraka i w szachy grali giermkowie / a jeszcze łowczy polowali na byki / było tam dużo citoli i fideli”), Poema de Fernán González, cuad. 689, s. 167. 
w mieście huk posłyszano, wedle tego, co głosi historia ${ }^{67}$. Zaś pani Lambra, kiedy go usłyszała i dowiedziała się, że to jej kuzyn Álvar Sánchez trafił w wieżę, wielce była $\mathrm{z}$ tego rada i z zadowoleniem rzekła w obecności pani Sanchy, swojej bratowej, i jej wszystkich siedmiu synów, którzy z nią tam siedzieli: „Widzicie teraz, przyjaciele, jak walecznym jest rycerzem Álvar Sánchez, bo ilu się tam zebrało, żaden nie umiał trafić w szczyt wieży, jeno on sam i więcej jest on wart sam jeden niż wszyscy pozostali" ${ }^{68}$. Kiedy pani Sancha i jej synowie usłyszeli te słowa, roześmieli się, zaś rycerze, że rozsmakowali się wielce w zabawie, co ją właśnie rozpoczęli, żaden nie zwrócił uwagi na słowa pani Lambry, tylko Gonzalo González, który był najmłodszym z siedmiu braci ${ }^{69}$. I wymknął się swoim

${ }^{67}$ Formuła segund dize la Estoria odnosi się do bliżej nieokreślonego, anonimowego tekstu źródłowego będącego podstawą opracowania legendy w kronice. Może to być niezachowana do czasów współczesnych pieśń epicka lub jej streszczenie prozą. Skrybowie, korzystając ze źródeł o określonymi autorstwie, podawali zwykle jego tytuł lub nazwisko twórcy.

${ }^{68}$ W C1344 pani Lambra mówi, że „nie odmówiłaby miłości mężowi tak zacnemu, gdyby nie był jej bliskim krewnym” („que non vedaría su amor a ombre tan de pro si non fuese su pariente tan llegado"), Crónica de 1344..., s. 362. Komentarz Lambry o wyraźnym podtekście seksualnym pozwala zinterpretować późniejsze działania Gonzala Gonzáleza jako starania o jej przychylność.

${ }^{69}$ W legendzie Gonzal González jest tym, który najczęściej podejmuje inicjatywę, co stawia go w centrum konfliktu typu zniewaga - zemsta, prowadzącego do śmierci wszystkich infantów. Wątek pierwszeństwa najmłodszego z braci podejmuje również Poema de Fernán González: „Don Diego Gonçalez, el ermano mayor; / Rodrigo, el mediano; Fernando, el menor; / todos tres fueron buenos, mas Fernando el mejor, / ca quito muy grand tierra al moro Almançor” („Pan Diego Gonzalez, najstarszy z braci; / Rodrigo, średni, Fernando najmłodszy; / wszyscy trzej byli dobrzy, ale Fernando najlepszy, / bo zabrał kawał ziemi Maurowi Almanzorowi”; cuad. 168), Poema de Fernán González, s. 81. Chronica Naierensis podaje, że po śmierci Sancha III z Nawarry Kastylijczycy chcieli wybrać na hrabiego jego syna, Ferdynanda, ponieważ był najmłodszy, co z kolei może sugerować istnienie jakieś dawnego zwyczaju, w którym linia dziedziczenia przechodziła na najmłodszego potomka: A. Barbero, M. Vigil, La formación del feudalismo en la Península Ibérica, Barcelona 1978, s. 398-399, za: J. Escalona, Épica..., s. 140-141. W C1344 uznanie Mudarry przez Sanchę i ojca jest możliwe tylko dzięki jego niezwykłemu podobieństwu do 
braciom, i dosiadł wierzchowca, i chwycił w dłoń włócznię ${ }^{70}$, a był sam jeden i nie było z nim innego człeka jak tylko jego giermek, co niósł mu jastrzębia. I Gonzalo González, gdy przybył na miejsce, cisnął włócznią do wieży i trafił w nią z taką siłą, że strzaskał jedną ze środkowych desek. A kiedy zobaczyła to pani Sancha i jej synowie, radowali się wielce, lecz pani Lambrze po prawdzie było przykro. Wówczas synowie pani Sanchy dosiedli wierzchowców i pojechali do brata, bo się obawiali, że wyniknie z tego jaka burda, co się potem zdarzyło, ponieważ Álvar Sánchez zaczął się chełpić, aż Gonzalo González musiał mu odpowiedzieć i rzekł: „Tak dobrze rzucaliście do wieży i tak się pannom podobacie, że zda mi się, że o żadnym innym rycerzu tyle nie prawią, co o was”. A wtedy rzekł Álvar Sánchez: „Jeśli panny o mnie prawią, słusznie czynią, bo wiedzą, że wart jestem więcej niż wszyscy inni”. Kiedy Gonzalo González usłyszał te słowa, ciężko mu się zrobiło na sercu i nie mógł zdzierżyć, więc ruszył na niego odważnie i tak mocno w twarz uderzył, że wybił mu zęby i wyłamał szczęki, od czego [Álvar Sánchez] padł martwy na ziemię u nóg swego wierzchowca. Pani Lambra gdy o tym usłyszała, zaczęła głośno zawodzić i zalewać się łzami, i powtarzała, że nigdy żadna panna nie została tak znieważona na swym własnym weselu jak ona ${ }^{71}$. Ruy Velázquez gdy się o tym dowiedział, wskoczył zaraz na konia i chwycił w rękę drąg, i ruszył tam, gdzie wszyscy byli [tj. nad rzekę], a gdy przybył do siedmiu infantów, uniósł w górę

Gonzala Gonzáleza, może więc, inaczej niż sądzą Barbero i Vigil, mamy tu do czynienia $\mathrm{z}$ wędrującym wątkiem folklorystycznym.

${ }^{70}$ Hiszp. bofordo: włócznia $\mathrm{z}$ tępym zakończeniem, używana również w bohurtach.

${ }^{71} \mathrm{~W}$ średniowiecznym prawie przewidywano surowe kary dla każdego, kto ośmieliłby się zaburzyć spokój zabawy weselnej. Fuero Real, kodeks z XIII wieku spisany za panowania Alfonsa X Mądrego, stanowi, że „si algún home deshonrare novio o novia el día de su boda, peche quinientos sueldos, é si los non hubiere, peche lo que hubiere, é por lo al yaga un año en el cepo" (Fuero Real, prawo 12, tytuł 5, księga 4: „Jeśli jakiś człowiek znieważy pana młodego lub pannę młodą w dniu ślubu, płaci pięćset soldów; a jeśli tyle nie ma, płaci, ile ma, i jeszcze przez rok będzie zakuty w dyby"), R. Menéndez Pidal, La leyenda..., s. 6. 
ramię z drągiem, który trzymał, i tak mocny cios zadał nim w głowę Gonzalowi Gonzálezowi, że z pięciu miejsc krew mu się puściła. Kiedy Gonzalo González zobaczył, że jest ciężko ranion, rzekł: „Na Boga, wuju, niczym sobie nie zasłużyłem, żebyście mnie tak ciężko obijali, lecz proszę mych braci, jeśli bym przypadkiem od tego wyzionął ducha, by nie dochodzili od was sprawiedliwości, i tak samo was proszę, miejcie litość i więcej mnie nie obijajcie, bo tego nie zdzierżę". Ruy Velázquez, gdy usłyszał te słowa, wielkim uniesiony gniewem zamierzył się po raz kolejny drągiem, aby znów uderzyć siostrzeńca, lecz Gonzalo González uchylił głowę przed ciosem, że ten go nie dosięgnął, jeno spadł na ramię, ale tak wielką ranę mu zadał, że złamał na nim drąg na dwa kawałki. Kiedy Gonzalo González zobaczył, że nie ma innej ani lepszej rady, chwycił jastrzębia, którego trzymał mu giermek, i uderzył nim Ruya Velázqueza mocno w twarz ${ }^{72}$ i do tego pięścią z taką siłą, że jednym ciosem całą twarz mu przeinaczył, od czego zaraz krew mu się puściła nosem. Wtedy Ruy Velázquez, gdy ujrzał, jak z nim źle, zaczął głośno krzyczeć i wołać „do broni, do broni”, w wielkim pośpiechu, zaraz też zebrali się przy nim wszyscy jego rycerze. Gdy infanci zobaczyli, co się dzieje, odsunęli się ze swoją kompanią na bok - a mogło być ich wszystkich z dwustu rycerzy bo dobrze widzieli, że do wielkiego nieszczęścia dojdzie, jeśli Bóg od niego nie odwiedzie. Lecz hrabia García Fernández, który był [ich] seniorem i przebywał w Burgos, oraz Gonzalo Gústioz, ojciec infantów, gdy dowiedzieli się o kłótni, ruszyli nad rzekę i stanęli między nimi, i ich rozdzielili, że do żadnego więcej nieszczęścia wtedy nie doszło. A tak dobrze się sprawili hrabia García Fernández i Gonzalo Gústioz, ojciec infantów, że ich potem ze sobą pogodzili. Rzekł wtedy Gonzalo Gústioz do Ruya Velázqueza: „Panie Rodrigu, trzeba wam wielu rycerzy, bowiem zyskaliście większą sławę w boju niźli

72 Motyw użycia jastrzębia jako broni pojawia się również w epice francuskiej: Anseïs de Metz (pieśń z XII w.), Yon de Metz (pieśń z XIII w.), obydwie należące do cyklu Lorraine, oraz Girart de Vienne (XII/XIII w.), pieśń należąca do cyklu o Wilhelmie Orańskim, I. Zaderenko, El tema de la traición..., s. 185-186. 
jakikolwiek inny człek, z tej to przyczyny Maurowie i chrześcijanie zazdroszczą wam wielce i się was obawiają. Dlatego pragnąłbym, aby moi synowie wam służyli i się od was uczyli, jeśli się zgodzicie i będziecie temu radzi, i żebyście byli dla nich dobrzy, by dzięki wam więcej się zasłużyli, bo są waszymi siostrzeńcami i nie lza im czynić niczego, jak tylko to, co wy rozkażecie i co uznacie za dobre”. A Ruy Velázquez zgodził się i zapewnił, że tak będzie.

[737] Rozdział o tym, jak siedmiu infantów zabiło wasala pani Lambry

Gdy spór został zażegnany i doszli do zgody, a wesele się zakończyło, wyjechał z Burgos hrabia García Fernández i ruszył na objazd swoich ziem $^{73}$, i zabrał ze sobą Ruya Velázqueza i Gonzala Gústioza oraz wielu innych rycerzy. Zaś pani Lambra z panią Sanchą, swoją szwagierką, oraz siedmioma infantami i owym Nuñem Salidem, którzy przebywali w Burgos razem z panią Lambrą, opuścili miasto i wyruszyli ku Barbadillo $^{74}$. A infanci, by sprawić przyjemność pani Lambrze, swojej wujence, pojechali w górę rzeki Arlanzy na łowy z jastrzębiami, a gdy nachwytali wiele ptactwa, zawrócili ku pani Lambrze i wszystkie jej oddali. Potem wjechali do ogrodów ${ }^{75}$, niedaleko pałacu, gdzie się zatrzymała pani Lambra, aby wypocząć i przyjemnie spędzić czas, podczas gdy przygotowywano południowy posiłek. A ponieważ byli w ogrodach, Gonzalo González zdjął ubranie i został w samej bieliźnie, i wziął swego jastrzębia na rękę, i poszedł go obmyć. Pani Lambra, gdy go tak ujrzała bez odzienia, poczuła ciężar na sercu i tak rzekła do swych panien: „Przyjaciółki, czy widzicie, jak Gonzalo González paraduje w samej bieliźnie? Wiem, że nie robi tego ot tak, ale by w nas miłość rozbudzić i możecie być pewne, że martwi mnie srodze, że tak mi się wywinie, a ja nie będę mieć nad nim prawa”. A gdy to rzekła,

${ }^{73}$ Chociaż główną siedzibą hrabiego Kastylii było w owym czasie Burgos, zwyczajem władców objeżdżał swoje ziemie wraz z całym „wędrującym” dworem.

74 tMP: Barvadiello.

${ }^{75}$ Hiszp. huerta: ogrody warzywne i sady rozciągające się wokół zamków, osad i miast. 
kazała wezwać jednego ze swych ludzi i rzekła: „Weź ogórek ${ }^{76}$ i napełnij go krwią, i idź do ogrodów, gdzie rozłożyli się infanci, i rzuć nim w pierś Gonzala Gonzáleza, tego, którego tu widzisz z jastrzębiem na ręce. A potem zaraz wracaj tu do mnie, tak szybko, jak tylko zdołasz, i nie bój się, bo ja cię osłonię. W taki to sposób odpłacę za tamten cios pięścią i śmierć mego kuzyna Álvara Sáncheza, bo ta błazenada niejednemu jeszcze zaszkodzi”. Człek ów uczynił wówczas tak, jak mu rzekła pani Lambra. Infanci, gdy zobaczyli, że się ku nim zbliża, sądzili, że wujenka posyła im jakąś strawę, bo obiad się już spóźniał, myśleli bowiem, że są z nią w zgodzie i że ich miłuje bez żadnego oszustwa, ale się w tym mylili. A gdy ów człek nadszedł, zamachnął się ogórkiem i rzucił nim, i trafił Gonzala Gonzáleza w pierś, tak jak jego pani mu kazała, i zabrudził go całkiem krwią, i uciekł. Pozostali bracia gdy ujrzeli, co się stało, zaczęli się śmiać, ale nie od serca. I rzekł im wtedy Gonzalo González: „Bracia, źle czynicie, że się śmiejecie, bo w ten sam sposób, jak tym ogórkiem, mógł mnie zranić czym bądź i zabić. A więcej wam jeszcze rzeknę, gdyby któremuś z was przytrafiło się to, co mnie, wolałbym nie przeżyć kolejnego dnia niż poniechać zemsty. A ponieważ bierzecie za zabawę czyn taki jak ten i taką zniewagę, sprawi Bóg, że jeszcze tego pożałujecie”. Rzekł wtedy Diego González ${ }^{77}$, kolejny brat: „Bracia, trzeba, byśmy tę sprawę

${ }^{76}$ Hiszp. cohombro, czyli ogórek melonowy (cucumis flexuosus), owoc odmiany melona przypominający z wyglądu ogórek, tyle że dłuższy i poskręcany niczym wąż, stąd jedna z jego ludowych, kastylijskich nazw to pepino serpiente, czyli wężowy ogórek. Scena z rzucaniem krwawym ogórkiem ma wyraźny podtekst seksualny, który ujawnia się $\mathrm{w}$ zestawieniu $\mathrm{z}$ wypowiedzią pani Lambry przekazaną przez C1344. Jej celem jest znieważenie męskości Gonzala Gonzáleza, prowokującego damy, być może nieumyślnie, kąpielą w samej bieliźnie. Ogórek jako narzędzie zniewagi nie pojawia się w żadnym innym tekście, a jego obecność w legendzie zachęca badaczy do nieraz dość zaskakujących interpretacji, jak te zawarte w artykule Johna R. Burta, The Bloody Cucumber and Related Matters in the 'Siete Infantes de Lara', „Hispanic Review" 50 (1982), s. 345-352.

77 tMP: Diago Gonçález. Najstarszy z braci, ulubiony przez ojca. Wzmianki o niejakim Diegu Gonzálezie zachowały się w dokumentach z X w., lecz jednoznaczna identyfikacja postaci jest niemożliwa. 
rozważyli, żebyśmy się nie dali tu ośmieszyć, bo wielka byłaby nasza hańba. Weźmy teraz nasze miecze ukryte pod płaszczami i ruszajmy za owym człowiekiem, a jeśli zobaczymy, że nas czeka i się nie boi, będzie to znaczyć, że uczynił całą rzecz dla żartu i trzeba nam go oszczędzić. Lecz jeśli zacznie uciekać ku pani Lambrze, a ona go osłoni, wiedzieć będziemy, że za jej radą tak uczynił i jeśli tak się zdarzy, nie ujdzie z życiem, choćby go chciała ochronić”. Gdy to rzekł Diego González, wzięli wszyscy miecze i ruszyli do pałacu, a ów człowiek, kiedy tylko ich ujrzał, uciekł zaraz ku pani Lambrze, a ona wzięła go pod swój płaszcz ${ }^{78}$. Wtedy rzekli do niej infanci: „Wujenko, nie zatrzymujcie owego człeka, chcąc go przed nami ochronić”. Rzekła ona: „Dlaczego nie? Przecie jest mym wasalem. A jeśli uczynił rzecz jaką, której nie powinien, trzeba, by wam wynagrodził, lecz tymczasem póki jest w mej władzy, radzę wam, byście nie czynili mu zła żadnego". Wtenczas rzucili się na nią i wyciągnęli siłą owego człeka, co to go miała pod płaszczem, i zabili go na miejscu tuż przed nią, że nie zdołała go już obronić, ani nikt inny w jej imieniu. A z ran, które mu zadawali, krew pryskała na czepek i na szaty pani Lambry, aż na koniec cała była we krwi ${ }^{79}$. Kiedy infanci dokonali dzieła, dosiedli

${ }^{78}$ Lambra czuje się upokorzona nie tylko napaścią na należącego do jej dworu człowieka, ale przede wszystkim pogwałceniem symbolicznej strefy nietykalności osobistej wyznaczonej przez płaszcz. Zgodnie z dawnym germańskim prawem płaszcz był znakiem ochrony, jaką noszący roztaczał nad chroniącą się pod nim osobą. Symbolika płaszcza rozpowszechniła się w świecie chrześcijańskim za sprawą przedstawień Mater Misericordiae. Szerzej na ten temat zob. R. Knapiński, Od „Pokrowy” do „Płaszcza Opieki”. Przeobrażenia motywu ikonograficznego „Mater Misericordiae”, „Studia Warmińskie” 39 (2002), s. 131-160. Przypadek podobny do zdarzeń z legendy opisuje Crónica de Alfonso XI, gdzie w rozdziale 71 wzmiankuje się historię żydowskiego poborcy podatków don Yusufa, którego przed linczem chroni infantka Izabela, osłaniając własnym płaszczem. R. Menéndez Pidal, La leyenda..., s. 6.

${ }^{79}$ Krew zabitego sługi kala jej szaty, co jest równoznaczne bezpośredniej agresji, a przez średniowieczne prawo uznawane za ciężką obrazę honoru. Menéndez Pidal (La leyenda..., s. 7) cytuje prawo Nawarry (Fueros de Navarra), które nawet za mniejsze przewinienie, to jest za zranienie człowieka $\mathrm{w}$ obecności szlachetnie urodzonej damy, przewiduje grzywnę w wysokości pięciuset soldów. Dlatego 
wierzchowców i rzekli swej matce, pani Sanchy, by z nimi jechała, co też uczyniła, i udali się do Salas, do swego domostwa i swych włości. Gdy zaś odjechali, nakazała pani Lambra ustawić katafalk na środku dziedzińca, odpowiednio naszykowany i przykryty płótnem jak dla zmarłych. I łzy lała, i przez trzy dni wraz ze swymi pannami tak wielki lament podnosiła, że aż dziw, i rozdarła swe szaty, zwąc się wdową, która ostała się bez męża ${ }^{80}$. Zostawiamy teraz opowieść o pani Lambrze i powiemy o panu Rodrigu, jej mężu, oraz panu Gonzalu Gústiozie.

[738] Rozdział o tym, jak Almanzor

pojmał pana Gonzala Gústioza w Kordobie za radą Ruya Velázqueza

Tymczasem, ponieważ hrabia García Fernández powrócił do Burgos z objazdu, w czasie którego wizytował swe ziemie, pożegnali się z nim w owym mieście pan Ruy Velázquez i pan Gonzalo Gústioz i ruszyli do Lary, gdzie mieli swoje żony. Gdy jechali traktem, doszły ich wieści o wszystkim, co zaszło i w jaki sposób, i gdy je poznali, zatroskali się tak wielce, że bardziej nie mogli, i nie wiedzieli, jak sprawie zaradzić, ale pojechali aż do Barbadillo razem we dwóch. Naówczas pan Gonzalo opuścił pana Rodriga i ruszył do Salas, do swej żony i synów.

wyciągnięcie przemocą wasala spod płaszcza Lambry i zabicie go na miejscu jest uczynkiem podwójnie uwłaczającym, a Lambra nie może puścić płazem tak ciężkiej zniewagi i będzie dążyć do zemsty. A ponieważ sama nie może jej dokonać, posłuży się rękami męża, Ruya Velázqueza.

${ }^{80}$ Lament po zmarłym był wręcz obowiązkiem kobiety, nakazanym przez kastylijskie prawo, J. Escalona, Épica..., s. 137. Lambra nazywa samą siebie wdową, ponieważ ograniczona rola społeczna kobiety uniemożliwia jej podjęcie samodzielnych działań prowadzących do zemsty, tym samym jej dyshonor staje się udziałem męża, gdyż to on odpowiada za dom, a zatem przejmuje na siebie obowiązek zarówno pomszczenia krzywd, jak i odpokutowania win członków rodu. Niemniej jednak Lambra nie jest bohaterką pasywną, poddającą się losowi w pokorze, jak na przykład Jimena, żona Cyda Bojownika. W pierwszej części pieśni aktywnie wpływa na rozwój akcji, dwukrotnie prowokując młodego Gonzala Gonzáleza do czynów, które uzna później za zniewagę. Ponosi też konsekwencje swoich decyzji, gdy Mudarra przybywa do Kastylii, by pomścić braci i ojca. 
Wtedy pani Lambra, gdy się dowiedziała, że nadjeżdża pan Rodrigo, wypatrywała za nim, a kiedy zobaczyła, że wchodzi do pałacu, pobiegła ku niemu z rozdrapaną twarzą, zalewając się łzami i rzuciła się mu do stóp, prosząc łaski, bo wielce ją turbuje zniewaga, jakiej wobec niej dopuścili się jego siostrzeńcy, i by przez wzgląd na Boga i swą roztropność wymierzył im sprawiedliwość. Rzekł wtedy pan Rodrigo: „Pani Lambro, zamilczcie, nie turbujcie się więcej i uspokójcie, bo wam obiecuję taką sprawiedliwość wymierzyć, że wszyscy będą o tym mówić"81. Później pan Rodrigo wysłał posłańca do pana Gonzala Gústioza, aby przybył następnego dnia na spotkanie sam na sam, ponieważ ma z nim wiele do pomówienia. Pan Gonzalo przybył więc następnego dnia ze swoimi siedmioma synami i rozmawiali pomiędzy Barbadillo a Salas o zniewadze pani Lambry, której dopuściło się siedmiu infantów, aż doszli do porozumienia i zgody, a wtedy infanci oddali się w ręce swego wuja pana Rodriga, by osądził rzecz podług tego, co kto zdziałał, oraz by uczynił, co uzna za dobre i sprawiedliwe. Don Rodrigo chętnie na to przystał i począł schlebiać swym siostrzeńcom nieszczerze i fałszywymi słowy, by się przed nim nie strzegli. Potem, po kilku dniach, wysłał znów pan Rodrigo słowo do pana Gonzala, by jeszcze raz przybył do niego w to samo miejsce, w którym się byli spotkali poprzednio, ponieważ znów ma z nim wiele do pomówienia. Następnego dnia, gdy się spotkali, rzekł Ruy Velázquez do Gonzala Gústioza: „Szwagrze, dobrze wiecie, jak wiele kosztowało mnie wesele i że hrabia García Fernández nie wspomógł mnie tak hojnie, jak się spodziewałem i jak powinien ${ }^{82}$,

${ }^{81}$ Po powrocie Ruya Velàzqueza Lambra zdaje mężowi relację ze zdarzeń, a ten planuje zemstę, która obejmuje nie tylko bezpośredniego winowajcę, Gonzala Gonzáleza, ale również jego braci oraz ojca. Odpowiedzialność zbiorowa, tak charakterystyczna dla wczesnofeudalnych społeczeństw, dotyczy wyłącznie męskich przedstawicieli zwaśnionego rodu, wykluczając z vendetty matkę infantów, rodzoną siostrę Velàzqueza.

${ }^{82}$ Zapomoga pieniężna dla wasala na zorganizowanie ślubu i wesela była zwyczajowym obowiązkiem seniora. W Pieśni o Cydzie król Alfons obiecuje przekazać trzysta srebrnych marek na przygotowanie wesela Elviry i Sol z infantami z Carriónu, Cantar de Mio Cid, w. 2103, s. 228. 
zaś Almanzor obiecał, że da mi na wesele dobre wspomożenie i sami wiecie, że tak jest. A jeśli się zgodzicie, będę wam bardzo wdzięczny, jeśli się do niego udacie z moimi listami i go pozdrowicie ode mnie oraz jeśli raz w listach, a dwa własnymi słowami przedstawicie wielkie wydatki, jakie byłem poniosłem i że bardzo mi trzeba jego wsparcia. A wiem dobrze, że będzie on chętny i da wam potem wielkie bogactwa, z którymi tu przyjedziecie, i podzielimy je między nas dwóch". Tak odparł Gonzalo Gústioz: „Panie Rodrigu, wielce jestem rad temu, o co prosicie i pojadę bardzo chętnie, by spełnić wasze życzenie". Gdy to usłyszał Ruy Velázquez, rad był z całego serca i wrócił do swego pałacu, i oddalił się z jednym Maurem, co go miał, który umiał pisać po arabsku, i nakazał mu spisać taki oto list: „Do Almanzora od Ruya Velázqueza, pozdrowienia dla przyjaciela, którego miłuję z całego serca. Czynię wam wiadomym, że synowie Gonzala Gústioza z Salas, tego, który wam ten list przywiózł, znieważyli wielce mnie i moją żonę, a że nie mogę się na nich zemścić tu, na chrześcijańskiej ziemi, tak, jakbym tego pragnął, posyłam wam tedy ich ojca, abyście go kazali ściąć, jeśli mnie miłujecie. A kiedy już to uczynicie, zwołam liczne wojsko i zabiorę ze sobą siedmiu infantów, i rozłożę się z nimi na polach Almenaru. Wy zaś tak samo zwołajcie swe wojsko i przybądźcie najszybciej, jak tylko możecie w to samo miejsce, bowiem będę tam na was czekać. I niech z wami przybędą Viara i Galve, którzy są mi wielkimi przyjaciółmi, zaś siedmiu infantów, mych siostrzeńców, nakażcie potem ściąć, ponieważ są to najbardziej przeciwni wam ludzie tu, w całym chrześcijańskim świecie, i najwięcej pragną wam zaszkodzić. Zatem gdy ich już zabijecie, chrześcijańskie ziemie staną się wam posłuszne, bowiem hrabia García Fernández ma w nich wielkie wsparcie i pomoc"s3. A gdy list został spisany i opieczętowany,

${ }^{83}$ Alexander Krappe (The Cantar de los Infantes de Lara and the Chanson de Roland, „Neuphilologische Mitteilungen” 25 (1924), s. 15-24), porównując legendę z Pieśniq o Rolandzie, zauważył liczne podobieństwa między obydwoma tekstami. W tym fragmencie porównuje list Velázqueza do rad Ganelona, który przekonuje Marsyla do zabicia Rolanda i dwunastu parów, nazywając ich najgorszymi wrogami Saracenów. Porównanie uzupełnia Angelo Monteverdi (Il Cantare degli Infanti di 
rozkazał ściąć owego Maura, który go napisał, by go nie wydał. Potem dosiadł wierzchowca i udał się do Gonzala Gústioza, i rzekł do swej siostry, pani Sanchy, gdy wszedł do pałacu Gonzala Gústioza, takie oto fałszywe słowa: „Siostro, wielce bogaty wróci z Kordoby, dokąd go posyłam, pan Gonzalo, jeśli Bóg pozwoli, bo tyle dostanie, że już na zawsze będziemy wszyscy opływać w bogactwa i niczego nam nie zbraknie”. A gdy rzekł tak siostrze, odezwał się do pana Gonzala: „Szwagrze, trzeba wam działać, pożegnajcie się więc z panią Sanchą i ruszajmy. Tę noc spędzimy w Bilvestre, bo jest wam po drodze". Pan Gonzalo pożegnał się tedy z żoną, synami oraz z panem Nuñem Salidem, ich piastunem, i dosiadł wierzchowca, i pojechali, on i pan Rodrigo, do Bilvestre. I całą noc rozprawiali między sobą, sam na sam, w tajemnicy przed innymi, i dał mu naówczas pan Rodrigo list, o którym rzekliśmy, że spisał go jego Maur, który to pan Gonzalo miał ze sobą zabrać. Następnego dnia rano dosiadł pan Gonzalo wierzchowca i pożegnał się z panem Rodrigiem i panią Lambrą, i ruszył swoją drogą. Potem, gdy dotarł do Kordoby, udał się do Almanzora i dał mu list Ruya Velázqueza, i jeszcze rzekł mu od siebie: „Almanzorze, miło was pozdrawia wasz przyjaciel Ruy Velázquez i prosi was, byście mu posłali odpowiedź na to, o czym pisze w owym liście”. Naówczas Maur otworzył list i go odczytał, a gdy ujrzał nikczemności w nim zawarte, porwał list i rzekł: „Gonzalu Gústiozie, cóż to za list mi przywozicie?”, a Gonzalo Gústioz odparł: „Nie wiem, panie”. Na co odparł Almanzor: „Zatem posłuchaj. Otóż Ruy Velázquez pisze mi, abym cię ściął, lecz ja, ponieważ jesteś mi bardzo miły, nie zamierzam tego uczynić, a tylko nakażę zamknąć cię w więzieniu”. I tak też zrobił. Potem wysłał pewną Mauryjkę szlachetnie urodzoną ${ }^{84}$,

Salas, „Studi Medievali” 7 (1934), s. 142, p. 3) o paralelę językową: Ganelon mówi, że jeśli Roland umrze "n’asemblereit jamais Carles si grant esforz” (w. 599), zaś Velázquez tłumaczy, że hrabia Kastylii ma w infantach wielkie wsparcie: „ca mucho ha en ellos grant esfuerço el conde don Garçi Ferrandes" (za: I. Zaderenko, El tema de la traición..., s. 181-182).

${ }^{84}$ W C1344 owa Mauryjka jest siostrą Almanzora, która niechętnie usługuje Gonzalowi Gústiozowi. W kronice pojawiają się dwa warianty narodzin Mudarry: 
aby na niego baczyła, służyła mu i dawała, czego będzie potrzebował. I zdarzyło się, że w kilka dni po zamknięciu pana Gonzala w więzieniu, gdy Mauryjka mu tam usługiwała, porozumieli się ze sobą i pokochali, i pan Gonzalo spłodził w niej syna ${ }^{85}$, którego nazwali później Mudarra González. I on właśnie pomścił swego ojca i swych braci, siedmiu infantów, za zdradę, jakiej dopuścił się Ruy Velázquez, bo zabił go za to, tak jak opowiemy dalej w tej historii. Ale teraz nie będziemy więcej prawić o tej sprawie, lecz powrócimy do opowieści o Ruyu Velázquezie i Almanzorze.

\section{[739] Rozdział o tym, jak Ruy Velázquez zwołał wojska i zabrał ze sobą siedmiu infantów}

Tymczasem, gdy już Ruy Velázquez wysłał Gonzala Gústioza do Kordoby, jak właśnie rzekliśmy, wezwał siedmiu infantów i rzekł im: „Siostrzeńcy, rzec wam pragnę, co zamierzam uczynić. Póki ojciec wasz jest w drodze do Almanzora i nie wrócił, chcę najechać mauryjskie ziemie i złupić je aż po pola Almenaru i jeśli wam się podoba towarzyszyć mi w tej wyprawie, bardzo będę z tego rad, a jeśli nie, zostańcie tu we włościach i ich strzeżcie”. Rzekli infanci: „Panie Rodrygu, nie wydaje się rzeczą stosowną, byście szli z wojskiem, a nas zostawiali we włościach, bo okazalibyśmy w ten sposób wielkie tchórzostwo”. Na co odparł pan Rodrigo: „Wielce mnie radują wasze

rozdział CCXLVIIbis powtarza wersję z PCG i tu Mauryjka jest szlachcianką niespokrewnioną z władcą Kordoby, zaś w rozdziale CCLII Gonzalo Gústioz dopuszcza się w gniewie i rozpaczy gwałtu na siostrze Almanzora, aby ta urodziła mściciela, czyli Mudarrę, Crónica de 1344..., s. 379, 401-403.

${ }^{85}$ Wątek księżniczki zakochanej w cudzoziemcu należy do folkloru i często pojawia się nie tylko w baśniach, ale również w eposach i romansach rycerskich. Menéndez Pidal (La leyenda..., s. 18) wymienia kilka księżniczek z epiki francuskiej, które - zakochane w cudzoziemskim rycerzu - opuszczają z nim rodzinny kraj. W epice hiszpańskiej dobrym przykładem jest Sancha, córka króla Nawarry, która pomaga hrabiemu Fernánowi Gonzálezowi wydostać się z więzienia i ucieka z nim do Kastylii, gdzie biorą ślub, Poema de Fernán González, cuad. 629-690, s. $158-167$. 
słowa”. Gdy już uzyskał od infantów odpowiedź, rozesłał we wszystkie strony wieści, że ci, co chcą przyłączyć się do wyprawy i zdobyć co nieco, niech się prędko szykują i niech do niego przybywają. Gdy ludzie się o tym zwiedzieli, cieszyli się wielce $\mathrm{z}$ nowin, bowiem panu Rodrigowi szczęście zawsze sprzyjało, jemu i tym, którzy z nim szli, we wszelkich najazdach. I przybyła ku niemu naówczas taka gromada ludzi, że aż dziw. Posłał wtedy giermka do swych siostrzeńców, by dosiedli wierzchowców i ruszyli w ślad za nim, bo czekał ich będzie w dolinie Febros. Infanci, gdy to usłyszeli, pożegnali się z matką, panią Sanchą, i prędko ruszyli w ślad za nim. A gdy tak jechali, rozmawiając między sobą, dotarli do zagajnika sosnowego, który rósł przy drodze i na jego skraju dostrzegli ptaki, które niosły im bardzo złą wróżbę ${ }^{86}$. Nuño Salido, który im towarzyszył, ich piastun i bardzo dobry wróż, bo dobrze umiał czytać znaki, wielce się zafrasował na widok owych ptaków, co tak złą i przeciwną ich zamiarom dawały wróżbę ${ }^{87}$, zwrócił się więc do infantów i tak im rzekł: „Chłopcy, błagam was, zawróćcie do Salas, do matki waszej, pani Sanchy, bo nie byłoby dobrze, gdybyście przy tych znakach jechali dalej. Odpoczniecie nieco w domu, zjecie i wypijecie, i może zdarzy się, że wróżba

${ }^{86}$ Wróżenie z zachowania dzikich ptaków było bardzo popularnym, choć zakazywanym przez Kościół i prawo zwyczajem, na przykład kodeks prawny Fuero Juzgo (VI, 2, 3) nakłada karę stu batów za posługiwanie się wróżbami. O tym, że zakazy w żaden sposób nie osłabiły wiary w przesąd, przekonują również przykłady zaczerpnięte z literatury. W Pieśni o Cydzie interpretacja lotu ptaków pojawia się trzy razy (w. 11, 859, 2625) i odpowiada późniejszemu rozwojowi wypadków, zaś kłótnia Nuña Salida i Ruya Velázqueza (w dalszej części tekstu) na temat znaczenia dostrzeżonego po drodze znaku świadczy o wadze, jaką przykładano do właściwej interpretacji przepowiedni. Menéndez Pidal (La leyenda..., s. 8) uważa również, że umiejętność odczytywania znaków była częścią wiedzy, jaką winien dysponować opiekun młodzieży rycerskiej, aby móc nad nią czuwać. Co ciekawe, nie wystarczyło zobaczyć złowróżbny znak, by zapowiadany przez niego los się dopełnił, aby nabrał mocy sprawczej, należało go przekroczyć.

${ }^{87}$ C1344 podaje szczegółowy opis gatunków oraz położenia złowróżbnych ptaków: najpierw po prawej stronie drogi Nuño Salido zobaczył czarnowrona, następnie kolejnego po lewej, a na końcu siedzącego na szczycie sosny orła, Crónica de $1344 \ldots$, rozdz. CCXLVIII, s. 380. 
się dla was odmieni”88. Rzekł tedy Gonzalo González, najmłodszy z braci: „Panie Nuño Salido, nie mówcie tak, bo sami dobrze wiecie, że to, co tu się nam pokazuje, nie jest dla nas, lecz dla tego, który szykuje najazd i znaki dla niego są wróżbą, bo znaczniejszy jest nie tylko od nas, ale i od wszystkich innych. Lecz wy, którzy już swój wiek macie, wracajcie do Salas, jeśli wam wola, bowiem my chcemy iść za naszym panem Ruyem Velázquezem". Rzekł tedy Nuño Salido: "Chłopcy, prawdę wam powiadam i nie cieszy mnie, że tą drogą chcecie podążać, bo widzę na niej znaki, które mówią, że nigdy więcej do domu nie wrócimy. Lecz jeśli chcecie je przekroczyć, ślijcie od razu matce wiadomość, by przykryła płótnem siedem katafalków i ustawiła je pośrodku dziedzińca, i opłakiwała was jak zmarłych”. Odparł mu raz jeszcze Gonzalo González: „Panie Nuño Salido, źle mówicie i szukacie śmierci, bo gdyby ktoś was usłyszał, za takie słowa byście zginęli. I mówię wam, że gdybyście nie byli moim nauczycielem, jak jesteście, sam bym was za nie zabił. Zakazuję wam, od teraz więcej mówić o tej sprawie, bo nie zawrócimy przez wasze nagabywania". Nuño Salido, wielce zatroskany tym, co usłyszał, tak im rzekł: „W złą godzinę was chowałem, bo nie dajecie wiary mojej dobrej radzie $\mathrm{w}$ tej sprawie. A skoro tak jest, błagam was, pożegnajcie się ze mną, nim zawrócę, bo dobrze wiem, że już nigdy więcej się nie zobaczymy”. Infanci lekce sobie ważąc słowa starego piastuna, pożegnali się z nim i ruszyli swoją drogą. Nuño Salido zawrócił do Salas i jadąc drogą, pomyślał, że źle uczynił, porzucając w ten sposób swych wychowanków, powodowany strachem przed śmiercią. Zwłaszcza że był już człekiem starym i miał już swoje lata, więc nie powinien był tak czynić pod żadnym pozorem, bo słuszniej było jemu iść tam, gdzie śmierć mógłby spotkać, niż im, którzy byli jeszcze młodzi i przed sobą mieli wiele życia. A jeśli oni nie obawiali się śmierci i za nic ją sobie

${ }^{88} \mathrm{~W}$ pierwszym odruchu, chcąc uniknąć zwiastowanej przez ptaki śmierci, Nuño Salido zawraca do Salas, jako że wycofanie się w porę odwraca zły urok. Zachęca też infantów, aby zawrócili do domu, odpoczęli w nim, coś zjedli i wypili, czyli oszukali przeznaczenie przez wykonywanie czynności codziennych, umożliwiających podjęcie wyprawy na nowo, już bez obciążającej ją złej wróżby. 
mieli, on tym bardziej nie powinien się jej obawiać. A jeszcze, gdyby zginęli podczas wyprawy, a Ruy Velázquez wrócił, wiele złego by mu za nich uczynił i by go zabił, i zawsze już by był na językach, gdyby coś podobnego uczynił. A więcej jeszcze, gdyby tam zginęli, uznaliby ludzie, że on to ich do śmierci doprowadził i że za jego radą to tego doszło. „Zła to dla mnie sława - rzekł do siebie - zdobyć w młodości honor, by go na starość utracić”. I gdy tak pomyślał, zawrócił w ślad za infantami ${ }^{89}$. Zostawiamy teraz Nuña Salida podążającego swoją drogą i opowiemy o siedmiu infantach.

\section{[740] Rozdział o tym, jak Ruy Velázquez groził Nuñowi Salidowi} i jak jedni i drudzy chcieli się tam pozabijać

Gdy siedmiu infantów pożegnało się z Nuñem Salidem, jechali tyle, aż dotarli do Febros, a pan Rodrigo, gdy ich zobaczył, wyjechał im na powitanie i rzekł, że już trzy dni na nich czeka. I zapytał o Nuña Salida, co z nim i dlaczego nie przyjechał razem z infantami. Naówczas opowiedzieli mu o wszystkim, co się im przydarzyło, gdy Nuño Salido odczytał znaki. Ruy Velázquez, gdy to usłyszał, zaczął im zaraz schlebiać i tak rzekł: „Chłopcy, owe znaki nam sprzyjają, bo znaczą, że na cudzym zdobędziemy wielkie łupy, a z naszego nic nie stracimy. I źle uczynił Nuño Salido, nie przyjeżdżając z wami, lecz oby Bóg sprawił, by pożałował swych uczynków i by nastał taki czas, w którym chciałby je naprawić, chociażby nie mógł”. A gdy tak prawili, nadjechał właśnie Nuño Salido. Infanci, gdy go ujrzeli, zaraz pięknie go powitali i bardzo się ucieszyli, ale rzekł wówczas Ruy Velázquez: „Panie Nuño Salido, zawsze byliście mi we wszystkim przeciwni i nawet w tej sprawie stajecie przeciwko mnie, lecz wielce byłbym strapiony, gdybym sprawiedliwości od was w tej kwestii nie

${ }^{89}$ Nuño Salido porównywany jest nie tylko do Maugisa z pieśni Renaut de Montauban, ale również do Oliviera z Pieśni o Rolandzie, który - ostrzeżony przez prorocze sny - radzi Rolandowi rozwagę, lecz ten go nie słucha. Olivier, tak samo jak Salido, mimo że wie, iż czeka go śmierć, bierze udział w bitwie; zob. A. Krappe, The Cantar..., za: I. Zaderenko, El tema de la traición..., s. 182. 
doszedł”. Odpowiedział mu zaraz Nuño Salido: „panie Rodrigu, nie popycha mnie wrogość, lecz prawda, i powiem każdemu, kto twierdzi, że znaki, które widzieliśmy, niosły pomyślną wróżbę, że łże niczym zdrajca i nie rzekł prawdy, ale że zdradę ma zaplanowaną i uknutą". A Nuño Salido prawił tak, bo wiedział już, co był rzekł Ruy Velázquez i z tej przyczyny tak mu prawił. Kiedy pan Rodrigo zobaczył, że Nuño Salido przeciw niemu występuje, uznał, że krzywda mu się dzieje i ten go znieważa, i wielce tym zasmucony, zaczął wołać: „Ach, wasale moi! W złej godzinie żołd wam wypłaciłem, bo widzicie przecie, jak Nuño Salido mnie znieważa, a nie bronicie mego honoru, a co gorsza, zdaje się, że wam to nawet nie wadzi”. Gdy to usłyszał pewien rycerz, którego zwano Gonzalo Sánchez, wyciągnął prędko miecz z pochwy i ruszył na Nuña Salida. Gonzalo González, gdy to zobaczył, rzucił się zaraz na owego rycerza i tak mocno uderzył go pięścią między szczękę a ramię, że ten padł martwy na ziemię prosto pod stopy Ruya Velázqueza. Ruy Velázquez wielce się tym strapił, zaczął wołać swoich i rozkazał im się zbroić, bo chciał się na siostrzeńcach pomścić, jeśli zdoła. Infanci i Nuño Salido, gdy to zobaczyli i pojęli, że wujowi ochota, by się z nimi bić, odsunęli się na bok wraz z dwustu rycerzami, których ze sobą przywiedli, i ustawili ich w szyku po jednej i drugiej stronie. Stanęli razem, blisko siebie, gotowi do walki, a wtedy Gonzalo González rzekł do Ruya Velázqueza, swego wuja: "Cóż to ma znaczyć? Wyciągnęliście nas tutaj z naszej ziemi, żeby bić się z Maurami, a teraz chcecie, żebyśmy się nawzajem wybili? Szczerze wam mówię, że mi się to nie podoba. A jeśli przypadkiem skarżyć nas chcecie za śmierć owego rycerza, którego zabiliśmy, chcemy wypłacić wam należne zadośćuczynienie, to jest pięćset soldów ${ }^{90}$ i dać je wam, i prosimy was, byście się zgodzili”. Pan Rodrigo, widząc, że nie nadeszła jeszcze pora, aby mogło się ziścić jego pragnienie tak, jakby tego chciał, a także nic by z niego nie wyszło, gdyby teraz zawrócili,

90 Zgodnie ze średniowiecznym prawem (Fuero Juzgo VIII, 4, 16) była to grzywna stałej wysokości za zabicie szlachetnie urodzonego mężczyzny, R. Menéndez Pidal, La leyenda..., s. 9. 
rzekł, że przystaje na propozycję i że mu się podoba. Teraz rzekniemy o nich i o Maurach.

[741] Rozdział o tym, jak walczyli Maurowie przeciw chrześcijanom i jak zginął Nuño Salido i Fernán González, jeden z siedmiu braci, i dwustu rycerzy, którzy z nimi byli

Gdy Ruy Velázquez rzekł swoje zdanie i wszyscy byli już na miejscu, zwinęli namioty i ruszyli w dalszą drogę. A następnego dnia wstali bardzo wcześnie i tak długo jechali, że jeszcze tego samego dnia dotarli na pola Almenaru. Pan Rodrigo ze swoimi ludźmi przyszykował wtedy zasadzkę w jednym dobrze ukrytym miejscu i rozkazał siostrzeńcom, żeby najechali pola i zrabowali, i porwali wszystko, co im wpadnie w ręce, i do niego wrócili. Lecz wcześniej posłał był już swój rozkaz do Maurów, żeby wygnali stada na pastwiska i sami wyszli, z tej strony, z której im lepiej odpowiada, więc wszystko to, co rozkazał infantom, było jeno oszustwem i złośliwością. Infanci pogalopowali tedy, by zrobić, co im wuj nakazał, lecz rzekł im Nuño Salido, ich piastun: „Chłopcy, nie trzeba wam brać łupów, bo nie będziecie mieć z nich korzyści, bo jeśli chwilę zechcecie poczekać, znajdziecie dużo więcej innych, które łatwo zdobyć i więcej jest ich niż tych”. Ci zaś, gdy tak słuchali, zobaczyli ponad dziesięć tysięcy nadciągających chorągwi i proporców, a kiedy je ujrzeli, Gonzalo González spytał Ruya Velázqueza: „Co to za chorągwie, które tu nadciągają?”. Odparł Velázquez: „Chłopcy, nie obawiajcie się, bo rzeknę wam, co to. Otóż sam najeżdżałem te pola już ze trzy razy i zdobyłem na nich wiele cennych łupów, i żaden człek ani Maur mi w tym nie przeszkodził. Dlatego owi Maurowie nikczemni, gdy się o tym zwiedzieli, podchodzili aż tutaj i rozstawiali się ze swymi proporcami i chorągwiami, tak samo jak teraz widzicie, żeby nas nastraszyć. Lecz wy ruszajcie odważnie i jedźcie grabić, i niczego się nie obawiajcie, bo jeśli trzeba, przyjdę wam z pomocą”. Rzekł, a potem się im wymknął i poszedł do Maurów. Zaś Nuño Salido, kiedy to zauważył, ruszył za nim, żeby zobaczyć i posłuchać, co ma do powiedzenia Maurom. Gdy Ruy Velázquez 
dotarł na miejsce, rzekł do Viary i Galvego: „Przyjaciele, nadszedł czas, byście wynagrodzili mi krzywdy, jakich doznałem od mych siostrzeńców, siedmiu infantów, bo mają ze sobą ledwo dwustu rycerzy, nie więcej. Idźcie zatem, znajdźcie ich i otoczcie, a żaden wam nie ujdzie z życiem, bo ja nie wspomogę ich w żaden sposób". Gdy Nuño Salido usłyszał te słowa, rzekł mu: „O, zdrajco i nikczemniku! Dopuściłeś się wielkiej zdrady względem swych siostrzeńców! Bóg ci za to odpłaci niepiękną nagrodą, bo póki świat istnieje, prawić ludzie będą o twej zdradzie". I Nuño Salido, gdy wyrzekł te słowa, ruszył prędko ku infantom, głośno wołając: „Do broni, chłopcy! Wasz wuj Ruy Velázquez knuje z Maurami, by was zabić!”. Oni zaś, gdy to usłyszeli, uzbroili się najprędzej, jak mogli i ruszyli galopem na swych wierzchowcach. Wtedy Maurowie, ponieważ było ich wielu, rozdzielili się na piętnaście linii i ruszyli w takim szyku na infantów, i ich otoczyli. Natenczas Nuño Salido, ich piastun, zaczął dodawać im ducha takimi oto słowy: „Chłopcy ${ }^{91}$, nie traćcie ducha i nie bójcie się, bo znaki, o których wam rzekłem, że są nam przeciwne, nie są. Więcej nawet, sprzyjają nam i znaczą, że zwyciężymy i zdobędziemy na naszych wrogach łupy. I jeszcze wam powiem, że ruszam teraz na pierwszą linię, więc polecam was Bogu". A gdy to rzekł, spiął rumaka ostrogami i rzucił się na Maurów z takim zapałem, że zabił i zrzucił z konia wielu. Maurowie zaś dopadli go kupą i tyle ran zadali, że ubili go na miejscu, bo nie miał skąd czekać pomocy. Zaraz też rzucili się wszyscy jedni na drugich w nieładzie i z taką odwagą zadawali razy i z tak wielką ochotą ze sobą się ścierali, że niebawem całe pole gęsto pokryły trupy. A bitwa rozegrała

$91 \mathrm{~W}$ oryginale hijos, synowie. Relacja między opiekunem a oddanym mu na wychowanie chłopcem była zwykle bardzo zażyła, czego odbiciem są określenia „ojciec” i „syn”, jakimi zwykli się posługiwać względem siebie. Również Ruy Velázquez zwraca się w ten sposób do infantów, ponieważ zostali mu oddani pod opiekę, a jego zdrada jest wyparciem się powierzonego obowiązku, podlegającym surowej ocenie społecznej. Natomiast śmierć Nuña Salida na polach Almenaru to ofiara, jakiej oczekiwano po dobrym wychowawcy, który winien być gotów oddać życie za swego podopiecznego. 
się tam tak wielka i tak sroga, że o większej nikt nie słyszał. I jak głosi historia, chrześcijanie walczyli w niej tak dobrze i tak dzielnie, że przebili się przez dwie linie Maurów i dotarli nawet do trzeciej $^{92}$, a po jednej i drugiej stronie padło wielu. Maurów padło tam ponad tysiąc, zaś chrześcijan dwustu i ostało się jedynie siedmiu infantów. Więc gdy zobaczyli, że nie ma innej drogi jak zwyciężyć lub umrzeć, polecili się Bogu i wzywając świętego apostoła Jakuba, rzucili się na wrogów i tak dzielnie sobie poczynali, tak dobrze walczyli i tylu Maurów usiekli, i taką w nich trwogę zasiali, że żaden nie śmiał do nich podejść. Lecz Maurów było tylu, że ani nie było im końca, ani jak im dać rady w żaden sposób. Rzekł natenczas Fernán González do pozostałych infantów i do siebie: „Bracia, nie traćmy ducha i walczmy z odwagą, bo nikt nas tu nie wspomoże, jeno sam Bóg. A ponieważ straciliśmy tu naszego piastuna Nuña Salida i naszych rycerzy, trzeba byśmy ich pomścili albo padli razem z nimi. A jeśli zdarzy się, że zmęczymy się w walce, wespniemy się na wznoszący się tutaj pagórek i tam odpoczniemy”. I tak też uczynili. A gdy wrócili do walki, z taką odwagą rzucili się na Maurów, że zdawało się, że mają dość siły, by się pomścić, gdyby tylko było to możliwe. I gdy tak dziesiątkowali Maurów, zdarzyło się, że Maurowie w wielkim ścisku zabili Fernána Gonzáleza, jednego z infantów. A że bracia zmęczyli się już walką, wydostali się ze ścisku i wspięli na owo wzgórze, o którym wcześniej rzekliśmy, a gdy oczyścili twarze z kurzu i potu, rozglądali się za swym bratem Fernánem Gonzálezem, lecz nigdzie go nie mogli dojrzeć i wielce się tym zatroskali, bo pojęli, że padł martwy. Teraz opowiemy, jak Maurowie zabili tam wszystkich.

92 Krappe, przedstawiając dowody na analogię strukturalną między Pieśnia o Rolandzie a legendą, zauważa, że w Pieśni o Rolandzie francuskie rycerstwo zwycięża dwa pierwsze ataki Saracenów i przegrywa przy trzecim starciu, podobnie jak infanci, którzy pokonują tylko dwie pierwsze linie. Analogia wydaje się jednak mało przekonująca, zważywszy na frekwencję, z jaką pojawia się w literaturze motyw trzech prób. A. Krappe, The Cantar..., za: I. Zaderenko, El tema de la traición..., s. 182 . 


\section{[742] Rozdział o tym, jak zginęło siedmiu infantów i dwustu rycerzy, którzy ich wspomagali}

Infanci, znalazłszy się w tak nędznym położeniu, uradzili między sobą, by wysłać do Viary i Galvego prośbę o zawieszenie broni, póki się nie dowiedzą, czy wuj ich, Ruy Velázquez, zechce przyjść im z pomocą, czy nie. I tak też uczynili ${ }^{93}$. Następnie udał się Diego González do Ruya Velázqueza i rzekł: „Panie Rodrigu, czy zamierzacie ruszyć nam z pomocą, bo Maurowie bardzo nas pognębili, a do tego zabili Fernána Gonzáleza, waszego siostrzeńca, i Nuña Salida, i dwustu rycerzy, których ze sobą przywiedliśmy”. Odparł na to pan Rodrigo: „Przyjacielu, idź szukać szczęścia gdzie indziej! Czemuż to sądzisz, że zapomniałem, jakiej obrazy dopuściliście się względem

93 Leo Jordan (Die Sage von den vier Haimonskindern, „Romanische Forschungen” 20 (1907), s. 74-87) zauważył podobieństwo między zdradą Ruya Velázqueza a zasadzką króla Yona, opisaną w pieśni Renaut de Montauban (XII w.). Renaut i jego trzej bracia popadają w niełaskę Karola Wielkiego, ponieważ Renaut w trakcie partii szachów zabija Bertholeta i musi uciekać z królewskiego dworu. Karol Wielki ściga braci, którzy chronią się na dworze króla Yona z Gaskonii, gdzie Renaut żeni się z jego siostrą. Karol Wielki domaga się jednak wydania zbiegów, a przerażony Yon wysyła braci w zasadzkę, w której zostają napadnięci przez rycerzy cesarza. Z opresji ratuje ich kuzyn Maugis, czarodziej. Jordan uważa obydwa epizody zdrady za strukturalnie identyczne, ponieważ w obydwu bliski krewny oszukuje braci i wysyła ich w zasadzkę, gdzie walczą z przeważającymi siłami. Ponadto w obydwu opowieściach przed bitwą pojawiają się złe znaki, które dowodzący drużyną brat lekceważy; zbliżając się do miejsca zasadzki, dostrzegają sztandary przeciwników; we francuskiej pieśni towarzysze braci uciekają, w legendzie o siedmiu infantach giną razem $\mathrm{z}$ nimi, mimo to $\mathrm{w}$ obydwu opowieściach młodzi bohaterowie nie przestają walczyć; po pierwszym ataku bracia wycofują się na wzniesienie; zauważają nieobecność jednego z braci; ranni i zmęczeni proszą o zawieszenie broni; Renaut i bracia oczekują pomocy od Maugisa, infanci od Ruya Velázqueza; Ogier Duńczyk, kuzyn Renauta, w odruchu współczucia każe wstrzymać atak i rozmawia z braćmi, podobnie jak Viara i Galve; francuscy rycerze grożą, że doniosą Karolowi Wielkiemu o próbie uratowania braci przez Ogiera, tak jak Ruy Velázquez grozi muzułmańskim dowódcom. Jest to jedyny przykład wpływu epiki francuskiej uznawany przez R. Menéndeza Pidala, La leyenda..., s. 536. I. Zaderenko, El tema de la traición..., s. $177-179$. 
mnie w Burgos, kiedy uśmierciliście Álvara Sáncheza, i względem mej żony, pani Lambry, kiedy to należącego do niej człeka wywlekliście spod jej płaszcza i zabiliście go na miejscu, ochlapując krwią jej suknie i czepek, a jeszcze o śmierci rycerza, którego zabiliście w Febros? Dobrzy z was rycerze, myślcie więc, jak się ratować i bronić, a we mnie nie pokładajcie nadziei, bo nie udzielę wam żadnej pomocy”. Diego González, gdy to usłyszał, zostawił wuja i zawrócił do braci, i rzekł im wszystko, czego się od wuja dowiedział. A gdy oni pogrążyli się w smutku, bo zobaczyli, że są sami bez żadnej pomocy, Bóg natchnął serca niektórych chrześcijan, co z Ruyem Velázquezem przybyli, by ruszyć im z pomocą. I odłączyło się od niego i jego kompanii z tysiąc rycerzy. A gdy mieli już wyruszać ku infantom, uprzedzili o swym zamiarze Ruya Velázqueza, a on ruszył za nimi i ich zawrócił takimi oto słowy: „Przyjaciele, zostawcie mych siostrzeńców, niech sami walczą, bo jeśli trzeba będzie, udzielę im wsparcia”. Natenczas zawrócili rycerze, chociaż wbrew chęci, jak głosi historia, bo dobrze rozumieli, że doszło do zdrady. Lecz później, gdy owi rycerze wrócili już do obozu, młodzieńcy znani ze zręczności w boju i dobrych czynów, wymknęli się po trzech albo czterech w tajemnicy przed panem Rodrigiem. I zebrało się ich z trzystu rycerzy w jednym miejscu i przysięgli, że za zdrajcę będą mieć każdego, kto nie zechce ruszyć z pomocą siedmiu infantom w walce na śmierć i życie. A jeśli przypadkiem Ruy Velázquez chciałby ich znowu zawrócić, usieką go na miejscu. Gdy już złożyli przysięgę, wskoczyli na konie i ruszyli najprędzej, jak mogli. Gdy infanci zobaczyli, że się ku nim zbliżają, sądzili, że to Ruy Velázquez jedzie, by ich zabić. Ale rycerze, podjeżdżając ku nim, wołali w głos: „Infanci, nie obawiajcie się, bo z pomocą przybywamy i chcemy tu razem z wami zginąć albo przeżyć, bo dobrze wiemy, że wasz wuj pragnie waszej śmierci”. A gdy już do nich dotarli, tak rzekli: „Lecz jeśli zdarzy się, że ujdziemy stąd z życiem, chcemy, byście nam obiecali, że staniecie przed nim w naszej obronie". I infanci obiecali, że tak uczynią, przysięgli i ułożyli się z nimi, że za wszystko im potem zapłacą. A gdy tak zrobili, ułożyli kontrakt i podpisali, ruszyli razem przeciw Maurom i wydali im bitwę tak zaciętą i gwałtowną, że nikt 
nigdy o lepszej nie słyszał, bo walczyło w niej tak niewielu rycerzy, jak niewielu było tam chrześcijan. A tak wielką liczbę Maurów w walce wytracili, że nim jeszcze którykolwiek [z rycerzy] padł martwy, wybili ponad dwa tysiące Maurów. Ale nareszcie, gdy tak walczyli w ścisku, Maurowie tak bardzo urośli w liczbie, że zabili tam owych trzystu rycerzy, którzy przyszli z pomocą infantom. Zaś infanci tak już się zmęczyli walką, że nie mieli sił, by podnieść ramię z mieczem. I gdy Viara i Galve zobaczyli ich, zmęczonych i osamotnionych, użalili się nad ich losem i wydostali ich ze ścisku i zabrali do swego namiotu. Następnie kazali ich rozdziać ze zbroi i dać chleb i wino. Gdy Ruy Velázquez dowiedział się, co zaszło, udał się do Viary i Galvego i rzekł im, że bardzo źle czynią, zostawiając przy życiu takich ludzi i że źle na tym wyjdą, bo jeśli [infanci] ujdą z życiem, nie wróci już nigdy do Kastylii, ale pojedzie prosto do Kordoby do Almanzora i postara się, żeby za swój uczynek zostali ukarani śmiercią. Gdy Maurowie usłyszeli te słowa, bardzo się przelękli i zasmucili srodze. Rzekł natenczas Gonzalo González: „Fałszywy zdrajco! Przywiodłeś nas, by najechać i pokonać nieprzyjaciół wiary, a teraz mówisz, żeby to oni nas zabili? Bóg ci nigdy nie wybaczy uczynku, jakiego się tu wobec nas dopuściłeś”. Viara i Galve rzekli natenczas do infantów: „Nie wiemy, co nam czynić, bo jeśli Ruy Velázquez, wuj wasz, uda się do Kordoby, jak to rzekł, na islam zaraz przejdzie i Almanzor da mu wielką władzę, i z tego powodu będzie nam wciąż szkodził. Dlatego, skoro tak się sprawy mają, odstawić was musimy z powrotem na pole, skąd was zabraliśmy, bo sami widzicie, że nie możemy nic innego uczynić". I tak zrobili. Maurowie, gdy zobaczyli infantów z powrotem w polu, uderzyli w bębny i rzucili się na nich ciżbą tak gęstą jak krople deszczu. [Infanci] wydali im zaś bitwę tak zaciętą jak wcześniej, a może nawet bardziej, bo w krótkim czasie padło tam, wedle tego, co głosi historia, dziesięć tysięcy sześćdziesięciu Maurów. A chociaż wszystkich sześciu infantów było dobrymi rycerzami i walczyli świetnie i z wielką odwagą, Gonzalo González, najmłodszy, dokonał dużo więcej niż pozostali. Lecz Maurów było tak wielu, że już w żaden sposób rady dać im nie mogli, bo zadawaniem kolejnych ciosów czuli się już zmęczeni i tym, że tylu już 
trupem położyli, nie zaś od ciosów, jakie Maurowie im zadawali, ani od żadnej innej szkody, jaką mogliby im uczynić. Natenczas byli tak wyczerpani walką, że nawet z miejsca nie mogli się już ruszyć, a tak samo ich konie, a gdyby nawet chcieli jeszcze walczyć, nie mieli już mieczy ani żadnej innej broni, bo wszystkie albo się im rozpadły, albo je stracili. Gdy Maurowie zobaczyli, że są bez broni, usiekli najpierw pod nimi konie, a gdy już ich spieszyli, rzucili się na nich tłumem Maurowie i pochwycili za ręce, rozbroili i nie czekając wiele, obcięli głowę każdemu z osobna w kolejności, w jakiej się narodzili, na oczach ich wuja Ruya Velázqueza, zdrajcy. Natenczas Gonzalo González, najmłodszy z siedmiu braci, którego dopiero mieli ściąć, gdy zobaczył swych braci z odrąbanymi głowami, pojął, że wszystkich zetną, aż przyjdzie jego kolej i tak zakończy żywot. Dlatego, z wielkiego żalu i złości, skoczył na Maura, który ścinał im głowy i zadał mu w gardło cios tak silny, że ten padł martwy na ziemię. I chwycił prędko miecz, którym ścinał im głowy i zabił nim więcej jak dwudziestu Maurów z tych, którzy zebrali się wokół niego, jak powiada historia. Lecz Maurowie nie zważali już na ciosy i tłumem go otoczyli, pochwycili za ręce i ścięli. A gdy wszystkich siedmiu infantów już nie żyło, tak jak właśnie rzekliśmy, Ruy Velázquez pożegnał się z Maurami i wrócił do Kastylii, do swoich włości w Bilvestre. Zaś Maurowie zebrali głowy siedmiu infantów oraz Nuña Salida i ruszyli z nimi do Kordoby.

[743] O tym, jak Gonzalo Gústioz został uwolniony z więzienia i powrócił do Kastylii, do swoich włości w Salas

Kiedy Viara i Galve przybyli do Kordoby, udali się do Almanzora i pokazali swemu panu głowy siedmiu infantów i Nuña Salida. Gdy Almanzor je zobaczył, wyjaśniono mu, do kogo należały, a wtedy przyjrzał się im i je rozpoznał dzięki temu, co mu opowiedziano, i zdawało się, że zasmucił się wielce z tego powodu, że zabito wszystkich w taki sposób. Potem nakazał obmyć je dobrze winem do czysta z krwi, którą były umazane, a gdy to uczyniono, nakazał rozłożyć białe prześcieradło na środku pałacu i ułożyć na nim wszystkie głowy w rzędzie i w porządku, w jakim infanci przyszli na świat, a obok 
głowę Nuña Salida. Następnie udał się Almanzor do więzienia, gdzie przebywał w niewoli Gonzalo Gústioz, ojciec siedmiu infantów, i gdy wszedł do środka i go zobaczył, tak rzekł: „Jak ci się wiedzie, Gonzalu Gústiozie?”. A Gonzalo Gústioz odparł: „Tak, panie, jak waszej miłości się podoba. Lecz teraz wielce rad jestem, że przybyliście tutaj, bo dobrze wiem, że od dzisiaj zechcecie okazać mi więcej litości i każecie mnie stąd wypuścić. I przyszliście do mnie, ponieważ zwyczajem jest wielkich i szlachetnych panów, że gdy senior przychodzi do swego więźnia, nakazuje go później uwolnić". Rzekł wtedy Almanzor: „Gonzalu Gústiozie, uczynię, co rzekliście, bo dlatego tu przyszedłem, lecz najpierw powiem, co następuje. Wysłałem me wojska do Kastylii i starły się w bitwie z chrześcijanami na polach Almenaru. Właśnie przyniesiono mi stamtąd osiem głów wielkich panów: siedem należało do młodzików, zaś jedna do człeka już starego. Chcę, żebyśs stąd wyszedł i je zobaczył, bo może będziesz mógł je rozpoznać, jako że moi dowódcy rzekli, że z Lary musieli pochodzić". Rzekł Gonzalo Gústioz: „Jeśli ich zobaczę, powiem wam, kim są i skąd pochodzą, bo w całej Kastylii nie ma rycerza, którego bym nie znał i nie wiedział, z jakiego domu pochodzi”. Nakazał wówczas Almanzor, by go uwolniono i poszedł z nim do pałacu, gdzie na prześcieradle leżały rozłożone głowy. I gdy Gonzalo Gústioz je zobaczył i rozpoznał, tak wielka rozpacz go ogarnęła, że w jednej chwili padł na ziemię niczym martwy, a gdy doszedł do siebie, zapłakał nad nimi tak gorzko, że aż dziw brał. Rzekł potem do Almanzora: „Znam ja te głowy bardzo dobrze, bo należały do mych siedmiu synów, infantów z Salas, ta zaś do Nuña Salida, piastuna, który ich wychował". Gdy to rzekł, ból nim owładnął tak wielki i tak nad nimi szlochał, że nie było człeka, który widząc go, umiałby płacz powstrzymać. A potem brał w ręce głowy, jedną po drugiej, i wymieniał wszystkie piękne czyny każdego z infantów ${ }^{94}$. I zdjęty wielką rozpaczą, chwycił miecz, który zauważył

${ }^{94}$ C1344 wymienia imiona wszystkich Gonzálezów, poczynając od najstarszego: Diego, Martín, Suero, Fernando, Ruy, Gustio i Gonzalo, Crónica de 1344..., rozdz. CCLII, s. 397-400. 
w pałacu, i zabił nim w obecności Almanzora siedmiu dowódców. Wtedy wszyscy Maurowie rzucili się go powstrzymać, by więcej krzywdy nie czynił naokoło. A on prosił Almanzora, aby rozkazał go zabić. Almanzor, współczując mu wielce, nakazał zaś, by nikt nie ośmielił się stawać mu na przeszkodzie. Kiedy Gonzalo Gústioz lamentował, rozpaczał i łzy lał z oczu obficie, podeszła ku niemu Mauryjka, o której rzekliśmy, że mu usługiwała, i rzekła: „Nie traćcie ducha, panie Gonzalu, otrzyjcie łzy i nie smućcie się, bo ja też miałam dwunastu synów, bardzo dobrych rycerzy, i zdarzyło się, że wszystkich dwunastu zabili mi jednego dnia w bitwie, ale przecie $z$ tego powodu nie straciłam ducha i umiałam znaleźć pociechę. A skoro ja, która jestem niewiastą, nie upadłam na duchu i nie doszło do tego, żebym odebrała sobie życie albo kazała je sobie odebrać, tym bardziej wy, którzy jesteście mężczyzną, winniście znaleźć pociechę. Bo lejąc obficie łzy nad synami, nigdy wynagrodzenia za krzywdę nie dostaniecie, co zaś zyskacie, tracąc w ten sposób życie?”. Natenczas odezwał się Almanzor: „Gonzalu Gústiozie, współczuję ci szczerze z przyczyny owego nieszczęścia i bólu, jakie stały się twoim udziałem, i z tego powodu chcę cię uwolnić z więzienia, w którym przebywasz. Dostaniesz wszystko, co potrzebne na drogę, a także głowy synów, i wracaj do swych ziem, do pani Sanchy, twojej żony”. Rzekł wtedy Gonzalo Gústioz: „Almanzorze, niech Bóg wam wynagrodzi wasze dobre uczynki, a również dobre słowa, których mi nie żałujecie. Oby nadeszły czasy, kiedy będę się mógł wam za nie odwdzięczyć”. Natenczas owa Mauryjka, która mu usługiwała, podeszła i wzięła go na stronę, i tak rzekła: „Panie Gonzalu, noszę pod sercem wasze dziecię, więc trzeba, żebyście mi rzekli, co uważacie, że powinnam uczynić”. On zaś odparł: „Jeśli przyjdzie na świat chłopiec, dajcie mu dwie piastunki, niech go dobrze chowają, a gdy dojdzie do wieku, kiedy dobro od zła zacznie odróżniać, powiedzcie mu, że jest moim synem i wyślijcie go do Kastylii, do Salas”. A gdy to rzekł, zdjął z palca złoty pierścień i przełamał go na pół, dał jej jedną połówkę i rzekł: „Tę połówkę pierścienia weźcie ode mnie jako znak. A gdy chłopiec dorośnie i go do mnie poślecie, dajcie mu ją i nakażcie, by dobrze jej pilnował i nie stracił, i by mi 
ją przyniósł. Bo gdy ją zobaczę, po niej go poznam"95. Skoro pan Gonzalo ustalił wszystko z Mauryjką i otrzymał od Almanzora wszelkie rzeczy potrzebne do podróży, pożegnał się z nim oraz z innymi szlachetnymi Maurami i wyruszył do Kastylii, do Salas, swoich włości. A krótko po jego odjeździe owa Mauryjka, o której rzekliśmy, wydała na świat syna. I w tajemnicy opowiedziała Almanzorowi, co się zdarzyło, oraz że owo dziecię jest synem Gonzala Gústioza. Wielce się Almanzor z tego uradował, wziął dziecko i kazał je chować dwu piastunkom, zgodnie z tym, co ojciec rzekł Mauryjce, i nadał mu imię Mudarra González. Nie będziemy teraz więcej o tym prawić, bo później wrócimy do opowieści w tej Historii, kiedy materia doprowadzi nas do odpowiedniego miejsca, i opowiemy teraz o królu Ramirze.

${ }^{95}$ Bardzo podobny wątek znajduje się w adaptacji francuskiej pieśni Galien, zamieszczonej w Il Viaggio di Carlo Magno in Ispagna, włoskiej kompilacji z XIV lub XV wieku: we włoskim tekście Oliwier, towarzysz Rolanda w Roncevaux, daje ciężarnej mauryjskiej księżniczce Portugalii połówkę pierścienia i miecz i poleca, by jeśli urodzi się dziewczynka, dała jej połówkę pierścienia, a jeśli chłopiec miecz, aby po nim rozpoznał syna, gdy kiedyś go zobaczy. Oliwier odjeżdża, a po dziewięciu miesiącach rodzi się Galeant, wychowywany przez króla Portugalii. Gdy osiąga wiek 22 lat, król wysyła go wraz z trzystoma rycerzami na pomoc królowi Marsylowi, wtedy też jeden z rycerzy nazywa młodzieńca bękartem. Galeant dowiaduje się od matki o swoim pochodzeniu i wyrusza na poszukiwanie Oliwiera, którego znajduje umierającego w wąwozie Roncevaux. Oliwier wydaje ostatnie tchnienie na rękach syna, a ten przysięga go pomścić, zabijając wielu Maurów. Menéndez Pidal (La leyenda..., s. 543-550), uznając podobieństwo między $G a-$ lienem a Legendą o siedmiu infantach $z$ Lary, dopuszcza wpływ francuskiej pieśni na konstrukcję legendy, ale tylko w części dotyczącej wątku Mudarry w wersji z C1344. Być może jednak zapożyczenia wystąpiły w obydwu kierunkach: najpierw legenda wpłynęła na autora włoskiej kompilacji, a później tekst włoski na de Barcelosa, zwłaszcza że, jak zauważa Zaderenko, najstarsza wersja francuskiej pieśni Galien, pochodząca z XIII w., nie zawiera omawianego tu wątku; I. Zaderenko, El tema de la traición..., s. 187-189. 
[751] Rozdział o tym, jak Mudarra González zabił Ruya Velázqueza i jak Almanzor zajął Coyanzę i złupił chrześcijańskie ziemie

W siódmym roku panowania owego króla Bermuda - a działo się to w roku 1006 albo 968 od Wcielenia Pańskiego, albo w 37 [panowania] Ottona, cesarza rzymskiego - w tym roku ów Mudarra González, syn owej Mauryjki, ukończył dziesiąty rok życia i Almanzor pasował go na rycerza. Ponieważ, jak powiada historia, wielce go miłował, bo był jego bliskim krewnym oraz ponieważ widział, że jest roztropny, dzielny i obyczajny, choć jeszcze dziecko. I owego dnia, gdy Almanzor uczynił go rycerzem, pasował razem z nim ze dwustu giermków pochodzących z tego samego co on rodu ze strony matki, aby mu służyli, chronili i mieli za swojego seniora. Ów Mudarra González, gdy dorósł i doszedł do odpowiedniego wieku, okazał się tak dobrym rycerzem i tak dzielnym, że gdyby nie Almanzor, nie byłoby lepszego wśród Maurów. A ponieważ wiedział już, bo Almanzor i matka opowiedzieli mu w sekrecie, jak zginęli jego bracia oraz jak jego ojciec został pojmany i znieważony ${ }^{96}$, rzekł pewnego dnia do swych rycerzy i całej swej drużyny: „Przyjaciele, dobrze wiecie, że ojciec mój, Gonzalo Gústioz, nacierpiał się wiele od krzywd niesprawiedliwych i nieprawych, nie zasłużywszy na nie, wiecie też, jak siedmiu infantów, moich braci, zabito podstępem i zdradą. Dlatego mówię wam, że teraz, kiedy już doszedłem do właściwego wieku, chcę jechać w chrześcijańskie ziemie i pomścić ich, jeśli zdołam. I chcę też wiedzieć, jakie jest wasze zdanie, więc mi je rzeknijcie”. Odparli mu natenczas w taki sposób: "Wszystko, co tobie zdaje się dobre, nam też się podoba, bo jesteśmy, by cię chronić, służyć ci i wykonywać twoje rozkazy". Gdy Mudarra González wysłuchał swych ludzi i otrzymał od nich odpowiedź, udał się do swej matki i wszystko jej opowiedział, a także rzekł, że chce jechać do ojca i wywiedzieć się, co się z nim dzieje, czy żyw jest, czy

96 W C1344 Mudarra poznaje swoje pochodzenie dopiero na własne żądanie, kiedy grając w szachy z królem Segurem, zostaje przez tego nazwany bękartem (fijo de nenguno) i uniesiony gniewem zabija króla szachownicą; Crónica de 1344..., rozdz. CCLIII, s. 407-408. 
martwy, i by mu dała znak, który dla niego zostawił, aby mógł go po nim rozpoznać. Ona zaś dała mu połówkę pierścienia, którą Gonzalo Gústioz był jej zostawił. A Mudarra González, skoro otrzymał pierścień, pożegnał się z matką i poszedł do Almanzora, i rzekł mu, że chce się udać do swego ojca i czy mu na to zezwoli. Odparł Almanzor, że mu zezwala i raduje go piękny uczynek, jakiego zamierza dokonać. Następnie przydzielił mu rycerzy i zaopatrzył w konie i oręż, i różne dobra, i wszystko, co potrzebne, by drużyna prezentowała się należycie i dostojnie. I wedle tego, co prawi historia, dał mu jeszcze z chrześcijan, których miał w niewoli, rycerzy i wielu innych chrześcijan. Zaś Mudarra, kiedy ujrzał, jak dobrze jest zaopatrzony, pożegnał się z Almanzorem i wszystkimi znamienitymi Maurami i wyruszył w drogę, a prowadził ze sobą wielką gromadę rycerstwa i liczny orszak. Gdy dotarli do Salas, udali się prosto do pałacu Gonzala Gústioza, zaś pan Gonzalo Gústioz, gdy ich zobaczył, spytał, kim są. Wówczas rzekł Mudarra González: „Panie Gonzalu, urodziłem się w Kordobie” i odszedł z nim na stronę, i rzekł, co powiedziała mu matka, że jest jego synem i że dała mu połówkę pierścienia, którą był jej zostawił jako znak, i że ma ją ze sobą. I wyjął ją i pokazał. Gdy Gonzalo Gústioz zobaczył połówkę pierścienia i poznał, że to ta sama, którą zostawił jego matce, i że wszystko to prawda, uścisnął Mudarrę z wielką radością. Wtedy Mudarra González zatrzymał się w domu ojca, a gdy nacieszyli się sobą i odpoczęli kilka dni, rzekł Mudarra González do swego ojca: „Panie Gonzalu, przybyłem tu, aby pomścić wyrządzoną wam zniewagę oraz śmierć siedmiu infantów, waszych synów, a mych braci. Zatem nie trzeba nam dłużej zwlekać”. A gdy to rzekł, pojechali we dwóch z całą kompanią Mudarry prosto do hrabiego Garcíi Fernándeza i zabrali ze sobą trzystu rycerzy. A gdy wkroczyli do pałacu, w którym przebywał hrabia, Mudarra González wyzwał na pojedynek Ruya Velázqueza, który również tam był, oraz wszystkich jego ludzi. A uczynił to Mudarra González z własnej woli, w obecności hrabiego. I odparł Ruy Velázquez, że za nic ma jego groźby, a nadto, że lepiej by zrobił, gdyby nie łgał przed obliczem swego seniora. Gdy Mudarra González usłyszał słowa Ruya Velázqueza, chwycił za miecz i ruszył na niego, lecz powstrzymał go w tym zamiarze hrabia García 
Fernández i nie pozwolił mu zaatakować. Potem kazał im zawrzeć pokój na trzy dni, bo na więcej Mudarra González nie chciał się zgodzić. A gdy tak postanowili, pożegnali się z hrabią $\mathrm{i}$ każdy wrócił do siebie. Lecz Ruy Velázquez nie śmiał za dnia jechać do Barbadillo i dopiero z nastaniem nocy wyruszył. Gdy Mudarra González dowiedział się o tym, przyszykował zasadzkę na trakcie, którym Ruy Velázquez miał przejeżdżać i kiedy ten nadjechał, wyskoczył Mudarra González z zasadzki i rzucił się na niego, wołając: „Umrzesz, wiarołomny, fałszywy zdrajco". I wołając te słowa, zadał mu cios mieczem tak potężny, że rozpłatał go aż do połowy i położył trupem. I wedle tego, co prawi historia, zabił tam jeszcze trzydziestu rycerzy z tych, co towarzyszyli Ruyowi Velázquezowi. Następnie, jakiś czas po śmierci hrabiego Garcíi Fernándeza, pojmał panią Lambrę, żonę Ruya Velázqueza, i kazał ją spalić. Ponieważ za życia hrabiego Garcíi Fernándeza nie chciał tego czynić, jako że była jego bliską krewną.

W tym samym roku Almanzor zebrał wielkie wojsko i najechał chrześcijańskie ziemie, i podszedł aż do Coyanzy - a Coyanza to gród, który dziś nazywają Valencia ${ }^{97}$ - i ją oblegał, i zajął. A następnie kazał ją zburzyć i zrównać z ziemią. Potem zaś zawrócił do Kordoby. $\mathrm{W}$ tym samym roku zmarł również cesarz Otton pierwszy, po nim zaś panował Otton drugi przez dziesięć lat.

\section{Bibliografia}

Alvar C., Alvar M., Épica medieval española, Madrid 1997.

Álvarez Borge I., Poder y relaciones sociales en Castilla en la Edad Media. Los territorios entre el Arlanzón y el Duero en los siglos X al XIV, Valladolid 1996.

Burt J.R., The Bloody Cucumber and Related Matters in the 'Siete Infantes de Lara', „Hispanic Review” 50 (1982), s. 345-352.

${ }^{97}$ Miejscowość w prowincji León, należącej do wspólnoty autonomicznej Kastylia i León. Początkowo nosiła nazwę Coyanza, później Valencia de Campos, zaś od około XIV wieku - Valencia de Don Juan. 
Cantar de Mio Cid, ed. A. Montaner, Barcelona 1993.

Chalon L., L'histoire et l'épopée castillane du Moyen Âge. Le Cycle du Cid, le Cycle des comtes de Castille, Paris 1976.

Chronicon Iriense, w: Historia Compostelana donde se incluyen las pruebas del tomo precedente, con otras muchas noticias de Papas, Cardenales, Obispos, Concilios, Reyes, Varones ilustres y en especial del primer Arzobispo de Santiago D. Diego Gelmirez, ed. H. Florez, Madrid 1765.

Crónica de 1344, edición y estudio, ed. I. Vindel, Bellaterra 2015, https://www.tdx.cat/ bitstream/handle/10803/386537/invilde1.pdf?sequence=1 (dostęp: 14.11.2019).

Crónica General de España de 1344, ed. D. Catalán, M. Soledad de Andrés, Madrid 1971.

Crónica Geral de Espanha de 1344, ed. L.F. Lindley Cintra, vol. 1-4, Lisboa 1951-1990.

Deyermond A., El «Cantar de Mio Cid» y la épica medieval española, Barcelona 1987.

Deyermond A., Historia y crítica de la literatura española. Edad Media, Barcelona 2001.

El califato de Córdoba en el "Muqtabis" de Ibn Hayyán. Anales palatinos del Califa de Córdoba al-Hakam II, por Isa ibn Ahmad al-Razi (360-364 H. = 971-975 J. C.), ed. y trad. E. García Gómez, Madrid 1967, s. 173-174.

Escalona J., Épica, crónicas y genealogías. En torno a la historicidad de la Leyenda de los infantes de Lara, "Cahiers de linguistique hispanique médiévale” 23 (2000), s. 113-176.

Estoria de Espanna Digital, on-line 2016, http://estoria.bham.ac.uk/edition/ (dostęp: 14.11.2019).

Fernández-Ordóñez I., La transmisión textual de la "Estoria de España" y de las principales "Crónicas" de ella derivadas, w: Alfonso X el Sabio y las crónicas de España, al cuidado I. Fernández-Ordóñez et al., Valladolid 2000, s. 219-260.

Fernández-Ordóñez I., Las Estorias de Alfonso el Sabio, Madrid 1992.

Historia Compostelana, ed. E. Falque, Madrid 1994.

Ibn Jaldún, húab al-Ibar, ed. J. Sahada, Beirut 1981-1983.

Isla Frez A., Ensayo de historiografía medieval. El Cronicón Iriense, „En la España medieval" 4 (1984), s. 413-431.

Jordan L., Die Sage von den vier Haimonskindern, „Romanische Forschungen” 20 (1907), s. 74-87.

Knapiński R., Od „Pokrowy” do „Płaszcza Opieki”. Przeobrażenia motywu ikonograficznego „Mater Misericordiae”, „Studia Warmińskie” 39 (2002), s. 131-160.

Krappe A., The Cantar de los Infantes de Lara and the Chanson de Roland, „Neuphilologische Mitteilungen” 25 (1924), s. 15-24.

Lacarra E., Sobre la historicidad de la leyenda de los Siete Infantes de Lara, w: Historicist Essays on Hispano-Medieval Narrative in Memory of Roger W. Walker, ed. B. Taylor, G. West, London 2005, s. 201-227.

Libro de Alexandre, ed. J. Caña, Madrid 2013.

Martin G., La historia alfonsí: el modelo y sus destinos, siglos XIII-XV, Madrid 2000. 
Martín J.-L., Pelayo Rodríguez, obispo de Santiago, „Anuario de los estudios medievales" 2 (1965), s. 467-477.

Martínez Diez G., El condado de Castilla, 711-1038: la historia frente a la leyenda, Madrid 2005.

Menéndez Pidal R., La leyenda de los Infantes de Lara, Madrid 1971.

Menéndez Pidal R., Los godos y la epopeya española, Madrid 1969.

Monteverdi A., Il Cantare degli Infanti di Salas, „Studi Medievali” 7 (1934), s. 113-150.

Pieśń o Cydzie, przeł. A.L. Czerny, Kraków 2003.

Poema de Fernán González, ed. J. Victorio, 5a ed., Madrid 2010.

Sasor R., Zaginiona epika kastylijska, „Terminus” 20 (2018), z. 3 (48), s. 351-380.

Serrano L., Cartulario de San Pedro de Arlanza, Madrid 1925.

Vaquero M., Siete infantes de Lara: historia y ficción en la épica castellana medieval, „Cahiers d'études hispaniques médiévales" 36 (2013), s. 83-102.

Zaderenko I., El tema de la traición en Los siete infantes de Lara y su tradición en la épica románica, „Bulletin of Hispanic Studies” 78 (2001), issue 2, s. 177-190. 